\title{
The Development of Korean Infant Vocal and Articulatory Development List
}

\author{
Jinsook Kim², Jieun Yoon², Hyejin Park², Kyeongyeon Park², Jihyeon Lee² \\ 'Division of Speech Pathology and Audiology, College of Natural Science, Hallym University, Chuncheon, Korea \\ ${ }^{2}$ Department of Speech Pathology and Audiology, Graduate School, Hallym University, Chuncheon, Korea
}

\section{국내 영아의 발성 및 조음발달 목록 개발}

김진숙 $\cdot$ 윤지은 ${ }^{2} \cdot$ 박혜진 $^{2} \cdot$ 박경연 $^{2} \cdot$ 이지현 ${ }^{2}$

한림대학교 자연과학대학 언어청각학부 ${ }^{1}$, 한림대학교 일반대학원 언어병리청각학과 ${ }^{2}$

\begin{abstract}
Purpose: The purpose of this study was to develop Korean Infant Vocal and Articulatory Development (KIVAD) list and to set up a baseline for ultimately applying for articulations and vocalization of infants' aural rehabilitation program. Methods: 24 normal hearing infants at $1-3$ month age group, 28 at $4-5,33$ at $6-7,34$ at $8-9,34$ at $10-11,35$ at $12-13,36$ at $14-15,23$ at $16-17,35$ at $18-$ 19,37 at $20-21$, and 43 at $22-24$ participated in this study. We videotaped and analyzed their 34,065 vocalizations and articulations. The vocalization samples were analyzed according to 24 types of vocalization, and then counted prevalence of a certain vocalization out of total. The articulation samples were analyzed by 17 vowels and 18 initial and seven final consonants. Two analysis methods were used. One was the proportion analysis showing a ratio of prevalence of production for a certain month period of each articulation. The other was the acquisition age analysis showing a percentage of infants who produced corresponding articulation more than three times out of total infants. Then the results were classified emerging level (25-49\%), acquisition level 1 (50-74\%) and acquisition level $2(75 \%$ and over). Based on these analyses, KIVAD was composed. Results: Vocal developmental section was presented at 'KIVAD_V' and articulatory developmental sections were presented at 'KIVAD_AA' and 'KIVAD_AB' based on two analysis methods. Conclusion: KIVAD can be utilized to determine an infant's vocalization and articulation level and be useful for setting a goal in the aural rehabilitation program for the hearing impaired infants.
\end{abstract}

Key Words: Infants, Early development of vocalization and articulation, Korean Infant Vocal and Articulatory Development list.

Received: February 13, 2017 / Revised: March 14, 2017 / Accepted: March 29, 2017

Correspondence: Jinsook Kim, Division of Speech Pathology and Audiology, College of Natural Science, Hallym University, 1 Hallimdaehak-gil, Chuncheon 24252, Korea

Tel: +82-33-248-2213 / Fax: +82-33-256-3420 / E-mail: jskim@hallym.ac.kr

\section{INTRODUCTION}

청각기관은 재태 연령 8주쯤 형상이 나타나기 시작하여 코 르티기관을 포함한 내이는 재태 연령 20주에 여러 감각기관 중 가장 먼저 성인의 형태를 갖추어 초기 기능을 할 수 있게 되고 말소리를 수용하는 능력도 생긴다(Del Rey et al., 1995). 1 6개 월의 영아는 태내기에 들은 초분절적인 정보를 바탕으로 초분 절적인 정보와 분절적인 정보에 대해 인지학습을 하는 것으로 생각된다. 이를 이용하여 태아는 청각적 정보뿐만 아니라 말소 리 정보를 암호화한다(Liberman et al., 1957). 7 12개월의 영 아는 청각인지과정에서 학습을 통하여 초분절적인 정보를 조직
화하고 의미 있는 분절적인 정보를 배우는 데 초점을 두며 네 가지 학습 메커니즘-인지기억, 연관학습, 통계적 학습, 사회적 상호작용과 경험에 대한 동기유발-을 통하여 학습한다(Houston, 2011). 영아는 만 1세 이전에 해당하는 언어이전기에도 자 신의 요구를 알리거나 의사소통을 하기 위해 울음, 가성적 울 음, 쿠잉(cooing), 옹알이와 같은 다양한 발성을 이용한다. 이러 한 초기 발성은 영아의 월령이 증가함에 따라 청각언어인지 능 력 및 말 산출 기관의 해부생리적 발달과 더불어, 생리적인 소 리에서 점차 모음과 자음 형태와 유사한 조음이 포함된 옹알이 로 발전한다. 이와 같이 생후 1년 동안의 초기 발성 및 조음 발 달이 이후 말 산출과 언어발달에 영향을 미친다는 사실은 여 
러 선행 연구에서 증명되었다(McCune et al., 1996; Oller et al., 1995; Piaget, 1952, 1962). 이는 여러 연구자들이 옹알이와 초기 말 산출 사이에 연속성이 있다고 주장하는 바와도 일치 한다(Davis \& MacNeilage, 1995; Storkel \& Morrisette, 2002). 영아의 초기 발성이 언어 및 의사소통에 중요한 역할을 하므로, 초기 발성 발달 수준을 평가하는 데 사용될 수 있는 여 러 도구들이 개발되었다. 가장 보편적으로 사용되는 도구로 Nathani et al.(2006)에 의해 개발된 The Stark Assessment of Early Vocal Development-Revised (SAEVD-R)가 있다. SAEVD-R은 Stark(1980)와 Oller(1980)에 의해 개발된 발성 발 달 단계인 SAEVD에서 사용된 발성 유형과 정의를 수정한 도 구로, 1 18개월 영아의 발성을 분류하고 특징짓기 위해 초기 발성 발달 단계를 다섯 단계로 나누어 23개의 하위발성 유형에 대해 정의하였다. SAEVD-R은 국내외 여러 연구에서 응용되 고 있다(Ha \& Park, 2015; Ha et al., 2014; Kim et al., 2015). 그러나 영어권 영아와 국내 영아 간 발성 발달 단계 및 발성 유 형에는 차이가 있어 SAEVD-R이 국내 영아의 발성 발달을 평 가하는 데 제한적인 것으로 확인되었다. 예를 들어 Ha et al. (2014)은 외국 영아는 9 15개월에 주로 4단계 발성을 국내 영아 는 5 단계의 발성이 주로 나타난다고 하였는데 이는 한국 영아 가 종성이나 다음절을 영어권 영아보다 비교적 일찍 산출하기 때문이라고 보고하였다. 또한 Kim et al.(2015)은 발성유형의 차이를 보고하였는데, 1 2, 9 12, 13 15개월에 가장 많이 산출 한 발성은 비교적 일치한 반면 3 5개월과 6 8개월은 국내 영 아가 더 상위발성을 산출한다고 보고하였다.

최근 영아를 대상으로 한 국내의 음소지각 연구에서 국내 영 아들의 음소 변별 능력이 모국어 중심의 능력임을 증명하였다. 예를 들어 5 7개월, $12 ~ 15$ 개월의 영아의 영어 음소 /1/과 /r/ 변 별 능력을 사건관련전위(event related potential)검사로 살펴본 결과, 한국어에서 구분하지 않는 음소인 $/ 1 /$ 과 $/ \mathrm{r} /$ 을 초기에는 잘 변별하였으나, 월령이 증가할수록 변별능력이 감소하여 모 국어 중심의 음소변별능력으로 전환하는 현상을 증명하였다 (Kim et al., 2012). 이는 생후 6 8개월, 10 12개월 일본 영아의 영어 음소 $/ 1 /$ 과 $/ \mathrm{r} /$ 변별 능력을 고개돌림 반응으로 살펴보았을 때, 10 12개월 영아에게서 외국어 음소 변별 능력이 감소함을 보고한 국외의 연구(Kuhl, 2004)와도 일치한다. 또한 대부분의 언어에는 폐쇄음과 파찰음이 유성음과 무성음의 이중대립체계 인 반면, 한국어에는 평음, 경음, 격음의 삼중대립체계이다. 이 는 매우 독특한 체계로, 특히 무성음 내 삼중대립체계가 존재 하는 언어는 전 세계에서 한국어가 유일하다. 이와 관련하여 Nam et al.(2015)은 한국어를 모국어로 습득하는 4 6, 7 9, 10 12개월 영아 54명을 대상으로 평음과 격음(/부/-/푸/)의 음 소 변별력을 측정하여, 10 12개월에서 두 음소를 유의미하게
구별하는 결과를 보고하여 약 10 개월 정도의 모국어 경험이 평 음과 격음을 변별하는 능력을 보유할 수 있도록 하는 점을 시 사하였다. 더욱이 한국어의 삼중대립체계에 해당하는 음소는 총 19 개의 자음 중 12 개(/ᄀᄀ/, /T/, /ㅋ/, /ㄷ/, /匹/, /E/, /ㅂ/, /피/, /ㅃ/, /ㅈ//, /ㅉ/, /ㅊ/)로, 한국어 초기 음소 지각을 위하여 한국 영아는 외국 영아와 매우 다른 과정을 거치는 것으로 본다.

2 3세 이상의 아동에서 음소습득과정과 능력을 관련하여 출현과 습득단계로 나누어 분석하는 방법이 국내외에서 사용 되고 있다. 출현이나 습득단계는 해당 월령에서 몇 퍼센트의 아 동이 해당 음소를 바르게 발음하는지로 분석한다. 일반적으로 25 49\%를 출현(emerging)단계, 50 74\%를 친숙(customary)단 계, 75 94\%를 숙달(acquired)단계, 95 100\%인 연령을 완전습 득(mastery)단계로 구분한다. 이를 이용한 국내 연구에서는 2 세에 /표/, /ㅁ/, /O/을 완전히 습득하고, 3세에 /ㅂ/, /ㅃ/, /匹ᄄ/, /E/을 완전히 습득하며, 4세에 /ㄷ/, /ㄴ/, /T/, /ㅎ/을 완전히 습 득한다고 보고하고 있다(Kim, 1996; Seok et al., 2002). 국외 연구에서는 주로 출현(emergence) 과 습득(acquisition)단계의 연령을 제시하는데 습득하는 특정 연령을 제시하기보다는 연 속선상에서 습득 연령을 표시하므로 서로 다른 백분율 기준이 제시되고 있다. 출현단계는 보통 50\% 미만이고 습득단계는 50, $75,90 \%$ 의 단계로 표기하고 있다(Dodd et al., 2003; Hua \& Dodd, 2000; Kim \& Stoel-Gammon, 2010). 이렇게 습득 단 계의 비율이 다른 것은 연구마다 연구 대상의 연령이 2세이거 나 3 세 혹은 그 이상도 해당되기 때문인데, 대상 연령이 어릴수 록 습득 연령의 인정 기준은 낮아지는 것으로 나타났다. 더욱 이 이러한 연구들은 성인과 같은 완전한 자모음을 분석하는 것 이 일반적인 방법이다. 따라서 2 3세 이전 영아기에 출현하고 습득하는 초기음소습득 특성을 파악할 수 없고, 영아기에 나 타나는 중요한 발성인 유사 자모음의 발달 특성도 파악할 수 없어, 24개월 미만의 영아의 음소습득 발달 과정을 확인하고 모국어별 발달 특성을 분석하는 연구가 필요하다.

Donegan(2002)에 따르면, 영어가 모국어인 경우 생후 1년 동 안에는 저모음이며 동시에 비원순모음인 모음 산출이 빈번하 고, 전설모음과 후설모음의 차이보다 고모음과 저모음의 차이 를 먼저 구분하여 산출한다고 보고하여 생후 1년 동안은 모음 산출이 지배적이더라도 모음의 조음 발달은 느리게 진행되는 점을 시사하고 있다. 그러나 이와 달리 한국어가 모국어인 경 우, 3 개월에 모음을 산출하고, 4 개월에 자음을 산출하기 시작 하여, 생후 1년 내에도 모음뿐 아니라 다양한 자음 산출이 이 루어진다는 점이 최근 보고되어(Kim et al., 2015) 모음 산출에 있어 모국어가 다른 국내와 국외 영아가 다르게 발달한다고 할 수 있다.

영어가 모국어인 경우 자음 산출에 관한 연구에서 초기 자 
음 목록에 비음, 파열음, 마찰음, 접근음(approximant), 순음 (labial), 치조음이 있다고 보고하였다(Grunwell, 1981). TtofariEecen et al.(2007)은 만 1세에 평균 4.4개의 자음 목록을 가지 고 있으며, 주로 $/ \mathrm{m} /, / \mathrm{d} /, / \mathrm{b} /, / \mathrm{n} /$ 이 출현한다고 보고하면서 조 음 방법에 따른 분류에서 파열음이 가장 많이 나타나고, 조음 위치에 따른 분류에서는 양순음과 치조음이 가장 많이 나타났 다. 파열음이 가장 많이 나타난 이유에 대해 Kent(1997)는 음향 적 특징이 분명하여 청지각적으로 뚜렷한 차이가 있을 뿐만 아 니라 산출하기에도 비교적 쉽기 때문일 것이라고 보고하였다. 국내 연구에서도 Moon \& Ha(2012)는 12 24개월의 구개열 유 아와 정상 영아 14 명을 대상으로 음운발달을 확인한 결과, 파 열음, 비음, 마찰음 순으로 산출한다고 보고하여 파열음을 가 장 먼저 산출한다고 보고하였다. 다른 연구 자료에서도 1 36개 월의 영아 86명의 자음 산출을 분석하여 6개월에 비음인 /미 과 파열음인 /비이 나타나고 이후 산출 순서는 파찰음과 유음 순이었다(Jang et al., 2005). 또한 1 24개월 영아를 대상으로 한 Kim et al.(2015)의 연구에서 양순음이자 비음인 /ㅁ을 가 장 많이 산출하였으며, 자음을 처음 나타내기 시작한 4 5개월 에서 파열음인 / ᄀ/과 / ㅂ/, 비음인 /ㅁ/, 마찰음인 /ㅎ/이 나타났 다. 따라서 국내외 영아의 자음 산출은 파열음이 먼저 나타나 는 것으로 보인다. 그러나 연구자마다 자음 산출 순서에 대해 조금씩 다르게 보고하였다. 아마도 연구 대상 연령에 따른 차이 가 있어 일치된 결과를 확인할 수 없는 것으로 보인다. 특히 12 개월 이내의 연령에서는 연구 자료가 불충분하여 자음 산출 시 기와 순서에 대한 구체적이고 신뢰도 있는 자료는 구할 수 없었 다. 또한 영어를 모국어로 한 해외의 자료와 비교해볼 때 산출 순서는 유사한 면이 있으나 산출시기가 서로 다르게 나타나 해 외 자료를 그대로 적용하기 어려워 국내 영아의 조음 산출 시기 및 순서를 체계적으로 정리할 필요가 있다.

본 연구는 국내 1 24개월 정상 영아의 초기 발성 및 조음 발 달 단계를 체계적으로 분석하여 한국어를 모국어로 하는 국내 영아의 발성 및 조음 발달 순서를 분석하고자 하였다. 정상 영 아의 발성 및 조음 발달 단계를 세부적으로 확인하고 평가할 수 있는 자료는 정상 영아의 발성 및 조음 발달을 체계적으로 이해할 수 있고, 청각장애 영아의 조기 청각언어재활 시, 발성 및 조음 발달을 객관적으로 분석할 수 있는 근거를 제시하여 재활의 목표 발성 및 조음 목록의 기준선을 결정할 수 있어 청 각장애 영아의 정상적 발성발달을 보다 구체적이고 쉽게 유도 할 수 있는 자료로 활용할 수 있을 것이다. 이러한 자료를 제시 하기 위하여 본 연구는 국내 정상 영아들의 발성 및 조음발달 특성과 단계를 분석하고 정리한 목록인 국내 영아의 발성 및 조음발달(Korean Infant Vocal and Articulate Development list, KIVAD)리스트를 개발하고자 하였다.

\section{MATERIALS AND METHODS}

\section{연구 대상}

1 24개월 정상 영아 53명(남: 28명, 여: 25명)을 대상으로 연 구 자료를 수집하였다. 모두 청각적 결함이 없는 영아로, 부모 의 보고와 동영상 촬영 시 관찰을 통하여 발달이 정상범위임 을 반복 확인하며 촬영하였다. 부모나 검사자가 영아의 발달에 있어 지연을 확인하고자 할 경우, 영유아 건강검진 사업의 일환 으로 보건복지부와 질병관리본부의 지원 하에 개발된 한국 영 유아 발달선별검사(Korean Development Screening Test for Infants \& Children, K-DST)로 발달 상 문제가 없는지 확인한 후 정상 영아만 연구진행을 하였다. K-DST는 영역별 발달을 종합적으로 평가하여 발달의 문제가 있는 영아 및 유소아를 선 별하기 위한 부모보고식 검사로, 6 개의 발달영역, 대근육운동, 소근육운동, 인지, 언어, 사회성, 자조영역을 평가한다. 더 나아 가 영아의 발성 및 조음발달능력이 6 개의 전반적인 발달 영역 과 어떻게 연계되는지 추후 확인할 수 있도록 K-DST의 월령구 간을 반영하여 본 연구의 월령구간도 1 3, 4 5, 6 7, 8 9, 10 11, 12 13, 14 15, 16 17, 18 19, 20 21, 22 24개월로 구분 하였다. 각 월령구간별 참여한 영아의 수는 $24,28,33,34,34$, $35,36,23,35,37,43$ 명이었고, 영아의 성장에 따라 53 명의 발성 을 해당 월령에서 분석하였다.

\section{자료 수집 및 분석 절차}

자료 수집을 위해 동영상 촬영을 실시하였다. 3 대의 캠코더 (Sony model SOC-HDR-XP100, SOC-HDR_XR150, SOCHDR-XR300; Sony, Tokyo, Japan)를 이용하여 2009년 11월 부터 2016년 1월까지 부모 혹은 연구자가 촬영을 진행하였다. 본 연구는 한림대학교 생명윤리위원회의 승인을 받았으며(IRB 번호: HIRB-2015-008), 연구를 진행하기에 앞서 영아의 부모 님들께 연구의 방법 및 목적에 대해 설명을 한 후, 동의와 협조 를 구했다. 자연스러운 발성과 조음 발달 단계를 확인하기 위하 여 촬영은 가정에서 부모와 영아가 장난감을 이용한 자유놀이 활동을 하며 한 회기 당 약 30 40분 실시하였으며, 부모에게 평상시와 동일하게 상호작용을 하도록 안내하였다.

자료 분석 시 모든 음성자료는 동영상 편집 프로그램(다음 팟 인코더 v 2.0 BETA; Daum Communication, Seoul, Korea) 을 이용하여 편집하였으며, 수집된 동영상을 보면서 영아의 발 화를 듣고 24 개의 발성유형으로 분류하여 분석하였다. 또한 SAEVD-R에서는 발성유형만을 분석하고 있어, 구체적인 조음 의 발달 체계를 확인하기 어려웠으므로 본 연구에서는 영아의 발화를 전사하여 이를 적절한 조음으로 분석하였다.

발성과 조음을 구분하여 분석하였으며, 발성분석은 SAEVD- 
$\mathrm{R}$ 에서 제시한 23 개의 발성 유형을 참고하고 수정하여 본 연구 의 24개의 발성유형 분석 자료를 제작하였다(Appendix 1). 이 자료는 SAEVD-R에는 제시되지 않은 국내 영아의 특징적인 발성유형인 ‘응을 포함하고 있으며, 발성유형의 정의를 국내 영 아에 맞도록 일부 수정하였다 예를 들어, SAEVD-R에서 제시 한 $\mathrm{CMPX}$ 의 예시인 $\mathrm{CCV}$ 의 경우 우리나라에서는 나타나지 않 아 CMPX 예시에서 이를 제외시켰다. 우리나라는 음절과 음절 이 연결될 때만 겹쳐지는 현상이 나타나고 한 음절 내에서는 자음이 겹쳐서 나타나는 현상이 거의 없기 때문이다. 24개의 유 형으로 분석한 발성은 해당 월령구간에서 특정 발성유형이 차 지하는 비율을 분석하여 월령구간별로 가장 많이 산출된 상위 3 개의 발성유형을 분석하였으며, 추가적으로 0.10 즉, $10 \%$ 이상 산출된 발성유형을 분석하였다. 발성유형별 $0 \%$ 가 2 개의 월령 구간에서 지속적으로 나타난 이후에 산출된 1 2\% 이하의 발 성은 무작위 발성으로 간주하였다. 여러 종류의 발성은 특정기 간에만 나타났다. 예를 들어, 아이가 성숙함에 따라 소멸되는 발성유형이 있고 이로 인해 초기 발성과 상위 발성의 경계가 비 교적 분명하게 나타났다. 조음분석은 분석해야 할 총량이 많 고, 기 존재하는 분석 방법을 토대로 구조적이고 체계적인 분 석을 실시하였다.

\section{자료 분석}

조음의 심층 분석은 17 개의 모음, 18 개의 초성 자음, 7 개의 종성 자음으로 구분지어 분석하였다. 발성의 생성 및 소멸과 달리 조음은 산출되기 시작하면 소멸되는 현상 없이 꾸준히 산 출량이 증가하여 해당 월령구간 내 산출률을 분석할 경우 발 달 과정의 진행 상황을 파악하기 어려웠다. 따라서 산출 시작 월령 분석으로 조음발달 특성을 파악하고자 하였으며, 이를 위 해 해당 음소의 총 산출 비율을 이용한 분석과 해당음소를 산 출한 인원의 비율을 이용한 분석의 두 가지 방법을 사용하였다. 첫째, 해당 음소의 총 산출 비율을 이용한 분석은 각 조음별로 $1 \sim 24$ 개월의 총 산출량 중 한 월령구간 내 해당음소의 산출량 이 차지하는 비율을 분석하는 방법이다. 각 음소마다 3 개의 월 령구간에서 연속적으로 0.01 즉, $1 \%$ 이상 산출되었을 때 해당 모음이 관찰되기 시작하였다고 판단하였으며, 3 개의 월령구간 에서 연속적으로 0.05 , 즉 $5 \%$ 이상 산출되었을 때 해당모음이 안정적으로 관찰되었다고 판단하였다. 따라서 $1 \sim 4 \%$ 를 시작단 계, 5 9\%를 안정단계, $10 \%$ 이상을 친숙단계로 정리할 수 있었 다. 둘째, 해당 음소를 산출한 인원의 비율을 이용한 분석은 3 번 이상 해당 조음을 발성한 아동이 해당 월령구간의 전체 인 원 중 차지하는 비율을 분석하는 방법이다. 25 49\%를 출현단 계, 50 74\%를 습득 1단계, $75 \%$ 이상을 습득 2단계로 분석하였 다. 또한 KIVAD 리스트는 24개월 미만의 정상 영아를 대상으
로 하여, 이 시기에 나타나는 유사자모음도 포함하여 성인과 같 은 완전한 자모음을 산출하기 이전의 조음도 분석하였다. 이렇 게 분석한 자료로 1 24개월 정상 영아의 발성 및 조음의 발달 과정을 이해할 수 있는 KIVAD리스트를 작성하였다.

분석자의 숙련도 및 체계성 확립을 위하여 학부에서 청각학 을 전공한 대학원 석사과정의 연구원은 SAEVD-R을 바탕으로 발성 샘플을 갖추고 있는 인터넷 사이트(http://www.vocaldevelopment.com)와 기존에 수집된 음성 샘플들을 이용하여 해 당 교수와 책임 연구원의 지도로 충분한 듣기 훈련을 마친 후 분석을 실시하였다. 분석 시 신뢰도를 위하여 발성들의 분석기 준은 연구원 2명이 인정하고 동의한 경우 해당 발성으로 인정 하였으며, 분석 과정에서 두 평가자 사이에 의견이 불일치할 경 우, 해당 연구에 참여하는 교수진과 연구원이 모두 참석한 가운 데 다시 확인하여 최종 결정한 후 자료를 정리하였다. 분석에 참여한 연구원이 동일한 아동의 발화를 듣고 분석하였을 때, 분석자간 일치도를 확인하여 $80 \%$ 이상의 일치도를 구현하여 신뢰도를 확보하였다.

통계분석은 발성유형 및 조음 종류가 월령구간별 차이가 있 는지 알아보기 위하여, 일원배치분산분석(one-way ANOVA) 을 이용하여 실시하였다. 월령구간을 독립변수로, 24 개의 발성 유형, 18 개의 초성 자음, 17 개의 모음, 7 개의 종성 자음의 발화 수를 종속변수로 분석하였다.

\section{RESULTS}

\section{발성유형 분석}

수집한 총 발성 수는 34,065 개였으며 월령구간별로 산출된 발성유형의 발성 수와 비율을 분석하여 Table 1에 제시하였다. 각 월령구간별 가장 많이 산출된 상위 3 개의 발성유형을 살펴 보면, 1 3개월은 CR, Q, F, 4 5개월은 F, F2, V, 6 7개월과 8 9개월은 $\mathrm{CR}, \mathrm{F}, \mathrm{V}$ 가 가장 많이 나타났다. 10 11개월은 $\mathrm{V}$, $\mathrm{V} 2, \mathrm{CVCV}, 12 \sim 13$ 개월과 14 15개월은 V, CVCV, CMPX, $16 \sim 77$ 개월은 V, V2, CVCV가 가장 많이 나타났으며, 18 19, 20 21, 22 24개월은 V, CVCV, CMPX가 가장 많이 나타났다. 월령이 증가함에 따라 $\mathrm{VEG}, \mathrm{CR}, \mathrm{Q}, \mathrm{Q} 2, \mathrm{~F}, \mathrm{~F} 2$ 등 초기단계의 발성이 줄어들고, $\mathrm{CV}, \mathrm{CVCV}, \mathrm{CMPX}, / \mathrm{y} /$ 등의 상위단계 발성 이 많이 나타났으며, $\mathrm{V}$ 는 1 3개월을 제외한 나머지 월령구간에 서 모두 가장 많이 산출된 3개의 발성 유형 중 하나였고, $\mathrm{CVCV}$, $\mathrm{CMPX}$ 와 같은 상위단계의 발성은 12 개월 이후부터 가장 많이 산출된 3 개의 발성유형에 분류되었다. 또한 해당 월령구간에서 특정 발성이 나타나는 비율을 분석하였을 때 비교적 많은 발성 으로 생각되는 $10 \%$ 의 산출비율은 주로 상위 3 개의 발성유형과 유사하였다. 
Table 1. Frequency and ratio of vocalization by age of infants

\begin{tabular}{|c|c|c|c|c|c|c|c|c|c|c|c|}
\hline \multirow{2}{*}{ Vocalization } & \multicolumn{11}{|c|}{ Age (months) } \\
\hline & $1-3$ & $4-5$ & $6-7$ & $8-9$ & $10-11$ & $12-13$ & $14-15$ & $16-17$ & $18-19$ & $20-21$ & $22-24$ \\
\hline VEG* & $\begin{array}{c}189 \\
(0.08)\end{array}$ & $\begin{array}{r}89 \\
(0.03)\end{array}$ & $\begin{array}{r}66 \\
(0.02)\end{array}$ & $\begin{array}{r}63 \\
(0.02)\end{array}$ & $\begin{array}{r}58 \\
(0.02)\end{array}$ & $\begin{array}{c}61 \\
(0.03)\end{array}$ & $\begin{array}{r}39 \\
(0.01)\end{array}$ & $\begin{array}{r}22 \\
(0.01)\end{array}$ & $\begin{array}{r}20 \\
(0.01)\end{array}$ & $\begin{array}{c}13 \\
(0.00)\end{array}$ & $\begin{array}{c}16 \\
(0.00)\end{array}$ \\
\hline $\mathrm{CR}^{*}$ & $\begin{array}{c}312 \\
(0.13)^{\ddagger}\end{array}$ & $\begin{array}{c}205 \\
(0.08)\end{array}$ & $\begin{array}{c}307 \\
(0.09)^{\dagger}\end{array}$ & $\begin{array}{c}249 \\
(0.08)^{\dagger}\end{array}$ & $\begin{array}{c}101 \\
(0.04)\end{array}$ & $\begin{array}{r}96 \\
(0.04)\end{array}$ & $\begin{array}{c}124 \\
(0.04)\end{array}$ & $\begin{array}{r}57 \\
(0.02)\end{array}$ & $\begin{array}{r}56 \\
(0.02)\end{array}$ & $\begin{array}{r}34 \\
(0.01)\end{array}$ & $\begin{array}{r}33 \\
(0.01)\end{array}$ \\
\hline $\mathrm{Q}^{*}$ & $\begin{array}{c}628 \\
(0.26)^{\ddagger}\end{array}$ & $\begin{array}{r}98 \\
(0.04)\end{array}$ & $\begin{array}{c}155 \\
(0.05)\end{array}$ & $\begin{array}{c}57 \\
(0.02)\end{array}$ & $\begin{array}{c}12 \\
(0.00)\end{array}$ & $\begin{array}{r}8 \\
(0.00)\end{array}$ & $\begin{array}{c}14 \\
(0.00)\end{array}$ & 0 & $\begin{array}{c}2 \\
(0.00)\end{array}$ & 0 & 0 \\
\hline Q2* & $\begin{array}{c}267 \\
(0.11)\end{array}$ & $\begin{array}{c}133 \\
(0.05)\end{array}$ & $\begin{array}{r}60 \\
(0.02)\end{array}$ & $\begin{array}{r}34 \\
(0.01)\end{array}$ & $\begin{array}{c}17 \\
(0.01)\end{array}$ & $\begin{array}{r}4 \\
(0.00)\end{array}$ & $\begin{array}{c}1 \\
(0.00)\end{array}$ & 0 & $\begin{array}{c}1 \\
(0.00)\end{array}$ & 0 & 0 \\
\hline $\mathrm{F}^{*}$ & $\begin{array}{c}535 \\
(0.22)^{\ddagger}\end{array}$ & $\begin{array}{c}485 \\
(0.19)^{\ddagger}\end{array}$ & $\begin{array}{c}439 \\
(0.13)^{\ddagger}\end{array}$ & $\begin{array}{c}410 \\
(0.13)^{\ddagger}\end{array}$ & $\begin{array}{c}121 \\
(0.04)\end{array}$ & $\begin{array}{c}129 \\
(0.06)\end{array}$ & $\begin{array}{c}123 \\
(0.04)\end{array}$ & $\begin{array}{c}57 \\
(0.02)\end{array}$ & $\begin{array}{r}59 \\
(0.02)\end{array}$ & $\begin{array}{c}32 \\
(0.01)\end{array}$ & $\begin{array}{c}31 \\
(0.01)\end{array}$ \\
\hline $\mathrm{F} 2^{*}$ & $\begin{array}{c}340 \\
(0.14)\end{array}$ & $\begin{array}{c}373 \\
(0.15)^{\ddagger}\end{array}$ & $\begin{array}{c}236 \\
(0.07)\end{array}$ & $\begin{array}{c}179 \\
(0.06)\end{array}$ & $\begin{array}{r}61 \\
(0.02)\end{array}$ & $\begin{array}{r}41 \\
(0.02)\end{array}$ & $\begin{array}{c}51 \\
(0.02)\end{array}$ & $\begin{array}{c}23 \\
(0.01)\end{array}$ & $\begin{array}{r}34 \\
(0.01)\end{array}$ & $\begin{array}{c}7 \\
(0.00)\end{array}$ & $\begin{array}{c}19 \\
(0.01)\end{array}$ \\
\hline $\mathrm{cV}$ & $\begin{array}{c}27 \\
(0.01)\end{array}$ & $\begin{array}{c}105 \\
(0.04)\end{array}$ & $\begin{array}{c}249 \\
(0.07)\end{array}$ & $\begin{array}{c}177 \\
(0.06)\end{array}$ & $\begin{array}{c}128 \\
(0.05)\end{array}$ & $\begin{array}{c}117 \\
(0.05)\end{array}$ & $\begin{array}{r}71 \\
(0.02)\end{array}$ & $\begin{array}{c}132 \\
(0.05)\end{array}$ & $\begin{array}{r}41 \\
(0.01)\end{array}$ & $\begin{array}{c}32 \\
(0.01)\end{array}$ & $\begin{array}{c}17 \\
(0.01)\end{array}$ \\
\hline $\mathrm{cv} 2$ & $\begin{array}{r}47 \\
(0.02)\end{array}$ & $\begin{array}{c}108 \\
(0.04)\end{array}$ & $\begin{array}{c}118 \\
(0.04)\end{array}$ & $\begin{array}{r}94 \\
(0.03)\end{array}$ & $\begin{array}{r}54 \\
(0.02)\end{array}$ & $\begin{array}{r}54 \\
(0.02)\end{array}$ & $\begin{array}{r}65 \\
(0.02)\end{array}$ & $\begin{array}{r}74 \\
(0.03)\end{array}$ & $\begin{array}{c}32 \\
(0.01)\end{array}$ & $\begin{array}{c}25 \\
(0.01)\end{array}$ & $\begin{array}{c}37 \\
(0.01)\end{array}$ \\
\hline $\mathrm{CH}$ & $\begin{array}{c}8 \\
(0.00)\end{array}$ & $\begin{array}{c}63 \\
(0.02)\end{array}$ & $\begin{array}{c}140 \\
(0.04)\end{array}$ & $\begin{array}{c}146 \\
(0.05)\end{array}$ & $\begin{array}{c}205 \\
(0.07)\end{array}$ & $\begin{array}{c}111 \\
(0.05)\end{array}$ & $\begin{array}{c}152 \\
(0.05)\end{array}$ & $\begin{array}{c}114 \\
(0.04)\end{array}$ & $\begin{array}{c}113 \\
(0.03)\end{array}$ & $\begin{array}{c}105 \\
(0.04)\end{array}$ & $\begin{array}{c}93 \\
(0.03)\end{array}$ \\
\hline $\mathrm{V}$ & $\begin{array}{c}14 \\
(0.01)\end{array}$ & $\begin{array}{c}471 \\
(0.18)^{\ddagger}\end{array}$ & $\begin{array}{c}717 \\
(0.22)^{\ddagger}\end{array}$ & $\begin{array}{c}824 \\
(0.27)^{\ddagger}\end{array}$ & $\begin{array}{c}643 \\
(0.23)^{\ddagger}\end{array}$ & $\begin{array}{c}382 \\
(0.17)^{\ddagger}\end{array}$ & $\begin{array}{c}554 \\
(0.19)^{\ddagger}\end{array}$ & $\begin{array}{c}518 \\
(0.20)^{\ddagger}\end{array}$ & $\begin{array}{c}611 \\
(0.17)^{\ddagger}\end{array}$ & $\begin{array}{c}339 \\
(0.11)^{\ddagger}\end{array}$ & $\begin{array}{c}389 \\
(0.12)^{\ddagger}\end{array}$ \\
\hline $\mathrm{V} 2$ & $\begin{array}{c}12 \\
(0.00)\end{array}$ & $\begin{array}{c}224 \\
(0.09)\end{array}$ & $\begin{array}{c}302 \\
(0.09)\end{array}$ & $\begin{array}{c}159 \\
(0.05)\end{array}$ & $\begin{array}{c}337 \\
(0.12)^{\ddagger}\end{array}$ & $\begin{array}{c}164 \\
(0.07)\end{array}$ & $\begin{array}{c}214 \\
(0.07)\end{array}$ & $\begin{array}{c}353 \\
(0.13)^{\ddagger}\end{array}$ & $\begin{array}{c}400 \\
(0.11)\end{array}$ & $\begin{array}{c}108 \\
(0.04)\end{array}$ & $\begin{array}{c}111 \\
(0.03)\end{array}$ \\
\hline $\mathrm{Vg}$ & $\begin{array}{c}1 \\
(0.00)\end{array}$ & $\begin{array}{c}28 \\
(0.01)\end{array}$ & $\begin{array}{c}39 \\
(0.01)\end{array}$ & $\begin{array}{c}41 \\
(0.01)\end{array}$ & $\begin{array}{r}43 \\
(0.02)\end{array}$ & $\begin{array}{r}50 \\
(0.02)\end{array}$ & $\begin{array}{r}38 \\
(0.01)\end{array}$ & $\begin{array}{r}25 \\
(0.01)\end{array}$ & $\begin{array}{r}29 \\
(0.01)\end{array}$ & $\begin{array}{c}31 \\
(0.01)\end{array}$ & $\begin{array}{r}35 \\
(0.01)\end{array}$ \\
\hline IN & $\begin{array}{c}11 \\
(0.00)\end{array}$ & $\begin{array}{r}2 \\
(0.00)\end{array}$ & $\begin{array}{c}17 \\
(0.01)\end{array}$ & $\begin{array}{c}15 \\
(0.00)\end{array}$ & $\begin{array}{r}25 \\
(0.01)\end{array}$ & $\begin{array}{r}4 \\
(0.00)\end{array}$ & $\begin{array}{c}7 \\
(0.00)\end{array}$ & $\begin{array}{r}4 \\
(0.00)\end{array}$ & $\begin{array}{c}3 \\
(0.00)\end{array}$ & $\begin{array}{c}14 \\
(0.00)\end{array}$ & $\begin{array}{c}4 \\
(0.00)\end{array}$ \\
\hline SQ & $\begin{array}{c}15 \\
(0.01)\end{array}$ & $\begin{array}{c}33 \\
(0.01)\end{array}$ & $\begin{array}{c}115 \\
(0.03)\end{array}$ & $\begin{array}{r}91 \\
(0.03)\end{array}$ & $\begin{array}{c}145 \\
(0.05)\end{array}$ & $\begin{array}{c}118 \\
(0.05)\end{array}$ & $\begin{array}{r}86 \\
(0.03)\end{array}$ & $\begin{array}{r}75 \\
(0.03)\end{array}$ & $\begin{array}{c}93 \\
(0.03)\end{array}$ & $\begin{array}{r}25 \\
(0.01)\end{array}$ & $\begin{array}{r}30 \\
(0.01)\end{array}$ \\
\hline MB & $\begin{array}{c}3 \\
(0.00)\end{array}$ & $\begin{array}{r}50 \\
(0.02)\end{array}$ & $\begin{array}{r}87 \\
(0.03)\end{array}$ & $\begin{array}{r}54 \\
(0.02)\end{array}$ & $\begin{array}{r}58 \\
(0.02)\end{array}$ & $\begin{array}{r}41 \\
(0.02)\end{array}$ & $\begin{array}{r}43 \\
(0.01)\end{array}$ & $\begin{array}{c}11 \\
(0.00)\end{array}$ & $\begin{array}{c}23 \\
(0.01)\end{array}$ & $\begin{array}{c}7 \\
(0.00)\end{array}$ & $\begin{array}{c}3 \\
(0.00)\end{array}$ \\
\hline $\mathrm{CV}^{*}$ & $\begin{array}{c}3 \\
(0.00)\end{array}$ & $\begin{array}{c}23 \\
(0.01)\end{array}$ & $\begin{array}{r}75 \\
(0.02)\end{array}$ & $\begin{array}{r}84 \\
(0.03)\end{array}$ & $\begin{array}{c}190 \\
(0.07)\end{array}$ & $\begin{array}{c}175 \\
(0.08)\end{array}$ & $\begin{array}{c}209 \\
(0.07)\end{array}$ & $\begin{array}{c}204 \\
(0.08)\end{array}$ & $\begin{array}{c}297 \\
(0.08)\end{array}$ & $\begin{array}{c}268 \\
(0.09)\end{array}$ & $\begin{array}{c}241 \\
(0.07)\end{array}$ \\
\hline $\mathrm{CB}$ & 0 & $\begin{array}{r}5 \\
(0.00)\end{array}$ & $\begin{array}{r}22 \\
(0.01)\end{array}$ & $\begin{array}{r}64 \\
(0.02)\end{array}$ & $\begin{array}{c}111 \\
(0.04)\end{array}$ & $\begin{array}{r}45 \\
(0.02)\end{array}$ & $\begin{array}{r}73 \\
(0.03)\end{array}$ & $\begin{array}{r}50 \\
(0.02)\end{array}$ & $\begin{array}{r}40 \\
(0.01)\end{array}$ & $\begin{array}{c}124 \\
(0.04)\end{array}$ & $\begin{array}{c}63 \\
(0.02)\end{array}$ \\
\hline $\mathrm{WH}^{*}$ & 0 & $\begin{array}{r}2 \\
(0.00)\end{array}$ & $\begin{array}{r}5 \\
(0.00)\end{array}$ & $\begin{array}{r}6 \\
(0.00)\end{array}$ & $\begin{array}{c}33 \\
(0.01)\end{array}$ & $\begin{array}{c}19 \\
(0.01)\end{array}$ & $\begin{array}{c}24 \\
(0.01)\end{array}$ & $\begin{array}{c}17 \\
(0.01)\end{array}$ & $\begin{array}{r}50 \\
(0.01)\end{array}$ & $\begin{array}{c}18 \\
(0.01)\end{array}$ & $\begin{array}{r}50 \\
(0.01)\end{array}$ \\
\hline $\mathrm{CV}-\mathrm{C}$ & 0 & $\begin{array}{r}24 \\
(0.01)\end{array}$ & $\begin{array}{c}33 \\
(0.01)\end{array}$ & $\begin{array}{r}20 \\
(0.01)\end{array}$ & $\begin{array}{c}100 \\
(0.04)\end{array}$ & $\begin{array}{c}44 \\
(0.02)\end{array}$ & $\begin{array}{c}129 \\
(0.04)\end{array}$ & $\begin{array}{r}90 \\
(0.03)\end{array}$ & $\begin{array}{r}84 \\
(0.02)\end{array}$ & $\begin{array}{c}18 \\
(0.01)\end{array}$ & $\begin{array}{c}18 \\
(0.01)\end{array}$ \\
\hline $\mathrm{CVCV}^{*}$ & $\begin{array}{c}1 \\
(0.00)\end{array}$ & $\begin{array}{c}13 \\
(0.01)\end{array}$ & $\begin{array}{r}78 \\
(0.02)\end{array}$ & $\begin{array}{r}95 \\
(0.03)\end{array}$ & $\begin{array}{c}208 \\
(0.07)^{\ddagger}\end{array}$ & $\begin{array}{c}189 \\
(0.08)^{\ddagger}\end{array}$ & $\begin{array}{c}250 \\
(0.09)^{\ddagger}\end{array}$ & $\begin{array}{c}369 \\
(0.14)^{\ddagger}\end{array}$ & $\begin{array}{c}547 \\
(0.15)^{\ddagger}\end{array}$ & $\begin{array}{c}481 \\
(0.16)^{\ddagger}\end{array}$ & $\begin{array}{c}532 \\
(0.16)^{\ddagger}\end{array}$ \\
\hline CMPX* & $\begin{array}{c}1 \\
(0.00)\end{array}$ & $\begin{array}{c}1 \\
(0.00)\end{array}$ & $\begin{array}{r}46 \\
(0.01)\end{array}$ & $\begin{array}{c}167 \\
(0.05)\end{array}$ & $\begin{array}{c}107 \\
(0.04)\end{array}$ & $\begin{array}{c}293 \\
(0.13)^{\ddagger}\end{array}$ & $\begin{array}{c}465 \\
(0.16)^{\ddagger}\end{array}$ & $\begin{array}{c}280 \\
(0.11)\end{array}$ & $\begin{array}{c}677 \\
(0.19)^{\ddagger}\end{array}$ & $\begin{array}{c}954 \\
(0.32)^{\ddagger}\end{array}$ & $\begin{array}{c}1039 \\
(0.31)^{\sharp}\end{array}$ \\
\hline $\mathrm{JN}^{*}$ & 0 & $\begin{array}{c}1 \\
(0.00)\end{array}$ & $\begin{array}{r}6 \\
(0.00)\end{array}$ & $\begin{array}{r}6 \\
(0.00)\end{array}$ & $\begin{array}{r}40 \\
(0.01)\end{array}$ & $\begin{array}{r}68 \\
(0.03)\end{array}$ & $\begin{array}{c}87 \\
(0.03)\end{array}$ & $\begin{array}{r}87 \\
(0.03)\end{array}$ & $\begin{array}{c}228 \\
(0.06)\end{array}$ & $\begin{array}{c}138 \\
(0.05)\end{array}$ & $\begin{array}{c}122 \\
(0.04)\end{array}$ \\
\hline DIP* & 0 & 0 & $\begin{array}{r}4 \\
(0.00)\end{array}$ & $\begin{array}{r}5 \\
(0.00)\end{array}$ & $\begin{array}{r}41 \\
(0.01)\end{array}$ & $\begin{array}{c}47 \\
(0.02)\end{array}$ & $\begin{array}{r}54 \\
(0.02)\end{array}$ & $\begin{array}{r}36 \\
(0.01)\end{array}$ & $\begin{array}{c}53 \\
(0.01)\end{array}$ & $\begin{array}{c}41 \\
(0.01)\end{array}$ & $\begin{array}{c}124 \\
(0.04)\end{array}$ \\
\hline $\mathrm{n}^{*}$ & 0 & $\begin{array}{r}20 \\
(0.01)\end{array}$ & $\begin{array}{c}14 \\
(0.00)\end{array}$ & $\begin{array}{c}12 \\
(0.00)\end{array}$ & $\begin{array}{r}5 \\
(0.00)\end{array}$ & $\begin{array}{c}31 \\
(0.01)\end{array}$ & $\begin{array}{c}16 \\
(0.01)\end{array}$ & $\begin{array}{c}27 \\
(0.01)\end{array}$ & $\begin{array}{c}115 \\
(0.03)\end{array}$ & $\begin{array}{c}155 \\
(0.05)\end{array}$ & $\begin{array}{c}360 \\
(0.11)\end{array}$ \\
\hline Total & 2,414 & 2,556 & 3,330 & 3,052 & 2,843 & 2,291 & 2,889 & 2,625 & 3,608 & 2,969 & 3,367 \\
\hline
\end{tabular}

The parenthesis is portion of a certain vocalization out of total vocalization for each month. ${ }^{*} p<0.05$, this means the vocalizations appeared differently by month showing statistical significance. ${ }^{\dagger}$ Top 3 types of vocalization for each month and ${ }^{*}$ more than 0.1 , per se $10 \%$ in prevalence ratio. VEG: vegetative, CR: crying sound, Q: quasi-resonant nuclei, Q2: quasi-resonant nuclei2, F: fully resonant nuclei, F2: fully resonant nuclei2, cv: consonant-like segment and vowel-like sound combination, cv2: consonant-like segment and vowel-like sound combination2, CH: chuckle, V: vowel, V2: vowel2, Vg: vowel glide, IN: ingressive sound, SQ: squeal, MB: marginal babbling, CV: consonant-vowel, CB: canonical babbling, WH: whisper, CV-C: consonant-vowel combination, CVCV: disyllables, CMPX: complex syllables, JN: jargon, DIP: diphthongs 
초기단계의 발성은 월령이 증가함에 따라 감소하다가 이내 소멸하는 것으로 나타났다. $1 \%$ 기준으로 소멸된 발성 유형을 살펴보았을 때, $\mathrm{VEG}$ 는 14 15개월에, $\mathrm{CR}$ 은 20 21개월에, $\mathrm{Q}$ 는 10 11개월에, Q2는 8 9개월, F는 20 21개월에, F2는 16 17개 월에 소멸하는 것으로 나타났다.

24개의 발성유형을 어음 같지 않은 소리(non speech-like) $\mathrm{VEG}, \mathrm{CR}, \mathrm{Q}, \mathrm{Q} 2, \mathrm{CH}, \mathrm{IN}, \mathrm{SQ}, \mathrm{WH}$ 와 그 외 어음 같은 소리 (speech-like)로 구분하여 분석을 실시하였을 때, 월령이 높아 질수록 어음 같지 않은 소리의 비율이 점차 줄어들고, 어음 같 은 소리의 비율이 높아졌다(Figure 1). 1 3개월의 경우 어음 같 지 않은 소리가 어음 같은 소리보다 더 큰 비율을 차지했으나, $4 \sim 5$ 개월 이후부터 어음 같은 소리가 어음 같지 않은 소리보다 높은 비율을 나타내어, 1 3개월과 4 5개월 월령구간 사이에 급격한 발성발달 변화가 이루어지는 현상을 확인하였다.

월령구간을 독립변수로, 발성유형을 종속변수로 설정하여 일 원배치분산분석을 실시한 결과, $\mathrm{VEG}, \mathrm{CR}, \mathrm{Q}, \mathrm{Q} 2, \mathrm{~F}, \mathrm{~F} 2, \mathrm{CV}$, $\mathrm{WH}, \mathrm{CVCV}, \mathrm{CMPX}, \mathrm{JN}, \mathrm{DIP}, / \mathrm{n} /$ 이 월령그룹 간 유의미한 차 이(<0.05)를 나타내었다. Bonferroni 수정을 이용하여 다중비 교를 실시한 결과, 반복측정 다중비교에서는 월령에 따른 유의 미한 차이를 보이지 않았고, 발성유형에 따른 유의미한 차이는 일부 발성유형에서 나타났다. 또한 일원배치분산분석 다중비교 에서도 발성유형에 따라 일부에서 유의미한 차이를 보였다.

\section{모음 분석}

모음을 총 30,667 개로 분석한 결과를 월령구간별로 산출 빈 도 및 비율을 분석하여 Table 2에 제시하였다. 모음은 3개월부 터 산출되었다. 모음의 산출시기와 영아의 성장에 따른 산출 빈 도 및 비율의 변화를 확인하기 위하여 해당 음소의 총 산출 비 율을 이용한 분석 방법에 따라 1 24개월의 산출량 중 한 월령 구간의 산출량이 차지하는 비율을 분석하였다. 예를 들어, / / /
의 경우 전 월령구간에서 산출된 / / /의 총 산출량 8,828 개 중 $1 \sim 3$ 개월의 / / / 산출량은 67 개로 0.01 즉, $1 \%$ 의 산출률을 나타 내었다. 모음의 산출 시기를 분석하기 위하여 해당 음소를 산출 한 인원의 비율을 이용한 분석 방법에 따라 분석하였을 때, $1 \sim 3$ 개월에 습득단계로 나타난 모음은 / / / $/ 50 \%)$ 와 / / (H)/(50\%) 이다. 4 5개월에 출현단계로 나타난 모음은 / $/ /(26 \%)$ 와 / / / (30\%)였고, 습득 1단계에 도달한 모음은 / / /(74\%)였다. 6 77개 월에 습득 2 단계에 도달한 모음은 / / /(79\%)와 / $/ /(85 \%)$ 였다. 12 13개월에 출현단계에 도달한 모음은 /T/(27\%)였고, 습득 1 단계에 도달한 모음은 $/ \mathrm{A} /(52 \%)$ 와 / //(73\%)였다. 14 15개월에 출현단계에 도달한 모음은 / / /(38\%)였고, 습득 2단계에 도달한 모음은 /An(H)/(76\%)였다. 16 17개월에는 /ㄱ//(47\%)가 출현단계 에 도달하였고, /T/(59\%)가 습득 1단계에 도달하였다. 18 19개 월에는 $/-1 /(77 \%)$ 와 $/ / /(81 \%)$ 가 습득 2단계에 도달하였고, 20 21 개월에는 /ㄱ//(67\%)가 습득 1단계에 도달하였다. 22 24개월 에는 / / / / $43 \%)$ 와 /교/(37\%)가 출현단계에 도달하였고, / / /(74\%) 가 습득 1단계에 도달하였으며, /ㄱ/(89\%)가 습득 2단계에 도달 하였다. 1 24개월에 출현단계에 도달하지 않은 것으로 나타난

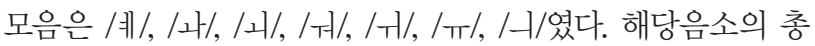
산출 비율을 이용한 분석 방법을 사용하였을 때 1 3개월에 시 작단계로 나타난 모음은 3개로 / / /, / / (H)/, / _ / 이고 해당음소 를 산출한 인원의 비율을 이용한 분석 방법을 사용하였을 때 출현단계로 나타난 모음은 없었고, / / / 와 / / (ㅐ)/가 습득 1단계 에 도달한 것으로 나타났다. 모음을 단모음과 이중모음으로 분 류하고 단모음은 다시 혀의 위치에 따라 전설모음, 중설모음, 후설모음으로 분류하여 살펴보았을 때, 중설모음, 전설모음, 후 설모음 순으로 발성발달 특성이 나타났으며, 이중모음은 초기 월령구간에는 나오지 않다가, 월령이 증가함에 따라 조금씩 산 출되기 시작하였다. 입술 모양에 따라 평순모음과 원순모음으 로 분류하여 분석하였을 때, 영아는 입술을 동그랗게 말아서

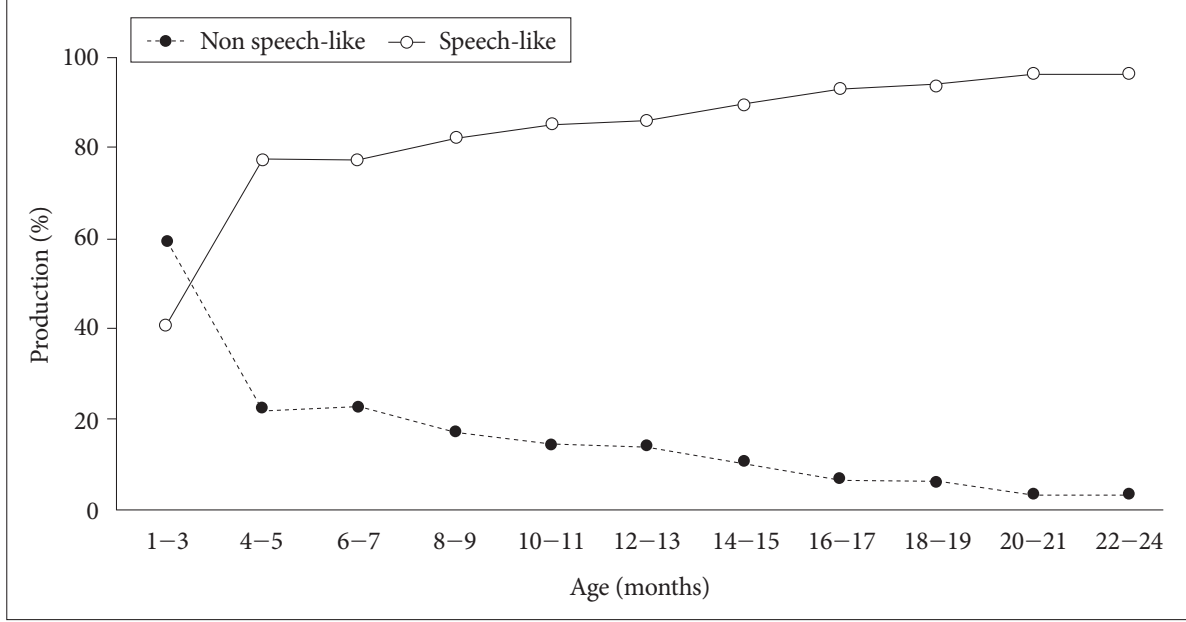

Figure 1. The production percentages of non speech-like and speech-like vocalizations as a function of month. 
Table 2. The raw frequency number, the portion of the production, and the percentage of infants who produced a certain vowel production for each month

\begin{tabular}{|c|c|c|c|c|c|c|c|c|c|c|c|c|}
\hline \multirow{2}{*}{ Vowels } & \multicolumn{11}{|c|}{ Age (months) } & \multirow{2}{*}{ Total } \\
\hline & $1-3$ & $4-5$ & $6-7$ & $8-9$ & $10-11$ & $12-13$ & $14-15$ & $16-17$ & $18-19$ & $20-21$ & $22-24$ & \\
\hline \multirow[t]{3}{*}{ t } & 67 & 311 & 542 & 997 & 567 & 1,125 & 995 & 479 & 951 & 1,278 & 1,516 & 8,828 \\
\hline & $(0.01)$ & $(0.04)$ & $(0.06)$ & $(0.11)$ & $(0.06)$ & $(0.13)$ & $(0.11)$ & $(0.05)$ & $(0.11)$ & $(0.14)$ & $(0.17)$ & \\
\hline & $50 \%$ & $65 \%$ & $79 \%$ & $75 \%$ & $96 \%$ & $97 \%$ & $97 \%$ & $100 \%$ & $90 \%$ & $94 \%$ & $94 \%$ & \\
\hline \multirow[t]{3}{*}{ k } & 1 & 12 & 9 & 10 & 25 & 54 & 58 & 42 & 89 & 105 & 247 & 652 \\
\hline & $(0.00)$ & $(0.02)$ & $(0.01)$ & $(0.02)$ & $(0.04)$ & $(0.08)$ & $(0.09)$ & $(0.06)$ & $(0.14)$ & $(0.16)$ & $(0.38)$ & \\
\hline & $0 \%$ & $4 \%$ & $9 \%$ & $0 \%$ & $15 \%$ & $9 \%$ & $38 \%$ & $29 \%$ & $39 \%$ & $48 \%$ & $74 \%$ & \\
\hline \multirow[t]{3}{*}{$\dashv$} & 5 & 55 & 56 & 68 & 121 & 186 & 347 & 115 & 394 & 381 & 914 & 2,642 \\
\hline & $(0.00)$ & $(0.02)$ & $(0.02)$ & $(0.03)$ & $(0.05)$ & $(0.07)$ & $(0.13)$ & $(0.04)$ & $(0.15)$ & $(0.14)$ & $(0.35)$ & \\
\hline & $0 \%$ & $26 \%$ & $24 \%$ & $19 \%$ & $38 \%$ & $52 \%$ & $72 \%$ & $71 \%$ & $77 \%$ & $70 \%$ & $89 \%$ & \\
\hline \multirow[t]{3}{*}{$H(H)$} & 126 & 389 & 431 & 489 & 180 & 334 & 247 & 82 & 304 & 379 & 571 & 3,532 \\
\hline & $(0.04)$ & $(0.11)$ & $(0.12)$ & $(0.14)$ & $(0.05)$ & $(0.09)$ & $(0.07)$ & $(0.02)$ & $(0.09)$ & $(0.11)$ & $(0.16)$ & \\
\hline & $50 \%$ & $65 \%$ & $73 \%$ & $56 \%$ & $65 \%$ & $64 \%$ & $76 \%$ & $53 \%$ & $71 \%$ & $79 \%$ & $83 \%$ & \\
\hline \multirow[t]{3}{*}{ F } & 0 & 0 & 0 & 0 & 2 & 3 & 29 & 18 & 18 & 50 & 90 & 210 \\
\hline & & & & & $(0.01)$ & $(0.01)$ & $(0.14)$ & $(0.09)$ & $(0.09)$ & $(0.24)$ & $(0.43)$ & \\
\hline & & & & & $0 \%$ & $0 \%$ & $3 \%$ & $12 \%$ & $10 \%$ & $21 \%$ & $43 \%$ & \\
\hline \multirow[t]{3}{*}{$\#($ 月 $)$} & 0 & 1 & 0 & 0 & 0 & 6 & 49 & 4 & 19 & 23 & 30 & 132 \\
\hline & & $(0.01)$ & & & & $(0.05)$ & $(0.37)$ & $(0.03)$ & $(0.14)$ & $(0.17)$ & $(0.23)$ & \\
\hline & & $0 \%$ & & & & $0 \%$ & $3 \%$ & $0 \%$ & $6 \%$ & $12 \%$ & $6 \%$ & \\
\hline \multirow[t]{3}{*}{ د } & 1 & 16 & 12 & 6 & 73 & 89 & 90 & 78 & 171 & 288 & 451 & 1,275 \\
\hline & $(0.00)$ & $(0.01)$ & $(0.01)$ & $(0.00)$ & $(0.06)$ & $(0.07)$ & $(0.07)$ & $(0.06)$ & $(0.13)$ & $(0.23)$ & $(0.35)$ & \\
\hline & $0 \%$ & $9 \%$ & $3 \%$ & $0 \%$ & $15 \%$ & $18 \%$ & $24 \%$ & $47 \%$ & $45 \%$ & $67 \%$ & $89 \%$ & \\
\hline \multirow[t]{3}{*}{ 가 } & 0 & 0 & 0 & 0 & 7 & 9 & 5 & 10 & 20 & 24 & 44 & 119 \\
\hline & & & & & $(0.06)$ & $(0.08)$ & $(0.04)$ & $(0.08)$ & $(0.17)$ & $(0.20)$ & $(0.37)$ & \\
\hline & & & & & $0 \%$ & $12 \%$ & $0 \%$ & $12 \%$ & $6 \%$ & $12 \%$ & $23 \%$ & \\
\hline \multirow[t]{3}{*}{ 기(개,제) } & 0 & 0 & 1 & 1 & 3 & 6 & 1 & 0 & 0 & 12 & 16 & 40 \\
\hline & & & $(0.03)$ & $(0.03)$ & $(0.08)$ & $(0.15)$ & $(0.03)$ & & & $(0.30)$ & $(0.40)$ & \\
\hline & & & $0 \%$ & $0 \%$ & $4 \%$ & $3 \%$ & $0 \%$ & & & $3 \%$ & $3 \%$ & \\
\hline \multirow[t]{3}{*}{ 표 } & 0 & 1 & 0 & 0 & 4 & 5 & 7 & 9 & 22 & 67 & 128 & 243 \\
\hline & & $(0.00)$ & & & $(0.02)$ & $(0.02)$ & $(0.03)$ & $(0.04)$ & $(0.09)$ & $(0.28)$ & $(0.53)$ & \\
\hline & & $0 \%$ & & & $0 \%$ & $0 \%$ & $0 \%$ & $12 \%$ & $10 \%$ & $18 \%$ & $37 \%$ & \\
\hline \multirow[t]{3}{*}{$T$} & 3 & 8 & 21 & 71 & 40 & 83 & 124 & 59 & 163 & 272 & 331 & 1,175 \\
\hline & $(0.00)$ & $(0.01)$ & $(0.02)$ & $(0.06)$ & $(0.03)$ & $(0.07)$ & $(0.11)$ & $(0.05)$ & $(0.14)$ & $(0.23)$ & $(0.28)$ & \\
\hline & $0 \%$ & $4 \%$ & $12 \%$ & $12 \%$ & $12 \%$ & $27 \%$ & $41 \%$ & $59 \%$ & $48 \%$ & $61 \%$ & $69 \%$ & \\
\hline \multirow[t]{3}{*}{ 거 } & 0 & 0 & 0 & 1 & 5 & 1 & 2 & 0 & 10 & 9 & 46 & 74 \\
\hline & & & & $(0.01)$ & $(0.07)$ & $(0.01)$ & $(0.03)$ & & $(0.14)$ & $(0.12)$ & $(0.62)$ & \\
\hline & & & & $0 \%$ & $4 \%$ & $0 \%$ & $0 \%$ & & $6 \%$ & $3 \%$ & $20 \%$ & \\
\hline \multirow[t]{3}{*}{ 가 } & 0 & 0 & 0 & 1 & 2 & 3 & 24 & 0 & 4 & 26 & 9 & 69 \\
\hline & & & & $(0.01)$ & $(0.03)$ & $(0.04)$ & $(0.35)$ & & $(0.06)$ & $(0.38)$ & $(0.13)$ & \\
\hline & & & & $0 \%$ & $0 \%$ & $3 \%$ & $7 \%$ & & $6 \%$ & $9 \%$ & $6 \%$ & \\
\hline \multirow[t]{3}{*}{$\pi$} & 0 & 0 & 0 & 4 & 3 & 8 & 9 & 5 & 10 & 17 & 22 & 78 \\
\hline & & & & $(0.05)$ & $(0.04)$ & $(0.10)$ & $(0.12)$ & $(0.06)$ & $(0.13)$ & $(0.22)$ & $(0.28)$ & \\
\hline & & & & $0 \%$ & $0 \%$ & $3 \%$ & $3 \%$ & $0 \%$ & $3 \%$ & $9 \%$ & $6 \%$ & \\
\hline \multirow[t]{3}{*}{-} & 132 & 763 & 1,050 & 778 & 656 & 910 & 680 & 479 & 594 & 788 & 2,062 & 8,892 \\
\hline & $(0.01)$ & $(0.09)$ & $(0.12)$ & $(0.09)$ & $(0.07)$ & $(0.10)$ & $(0.08)$ & $(0.05)$ & $(0.07)$ & $(0.09)$ & $(0.23)$ & \\
\hline & $0 \%$ & $74 \%$ & $85 \%$ & $72 \%$ & $81 \%$ & $94 \%$ & $93 \%$ & $82 \%$ & $94 \%$ & $97 \%$ & $97 \%$ & \\
\hline
\end{tabular}


Table 2. The raw frequency number, the portion of the production, and the percentage of infants who produced a certain vowel production for each month (continued)

\begin{tabular}{|c|c|c|c|c|c|c|c|c|c|c|c|c|}
\hline \multirow{2}{*}{ Vowels } & \multicolumn{11}{|c|}{ Age (months) } & \multirow{2}{*}{ Total } \\
\hline & $1-3$ & $4-5$ & $6-7$ & $8-9$ & $10-11$ & $12-13$ & $14-15$ & $16-17$ & $18-19$ & $20-21$ & $22-24$ & \\
\hline \multirow[t]{3}{*}{ - } & 0 & 0 & 0 & 0 & 0 & 1 & 1 & 0 & 2 & 6 & 4 & 14 \\
\hline & & & & & & $(0.07)$ & $(0.07)$ & & $(0.14)$ & $(0.43)$ & $(0.29)$ & \\
\hline & & & & & & $6 \%$ & $0 \%$ & & $0 \%$ & $3 \%$ & $3 \%$ & \\
\hline \multirow[t]{3}{*}{ l } & 6 & 49 & 113 & 79 & 83 & 272 & 252 & 96 & 326 & 502 & 914 & 2,692 \\
\hline & $(0.00)$ & $(0.02)$ & $(0.04)$ & $(0.03)$ & $(0.03)$ & $(0.10)$ & $(0.09)$ & $(0.04)$ & $(0.12)$ & $(0.19)$ & $(0.34)$ & \\
\hline & $0 \%$ & $30 \%$ & $30 \%$ & $31 \%$ & $42 \%$ & $73 \%$ & $62 \%$ & $65 \%$ & $81 \%$ & $82 \%$ & $97 \%$ & \\
\hline Total & 341 & 1,605 & 2,235 & 2,505 & 1,771 & 3,095 & 2,920 & 1,476 & 3,097 & 4,227 & 7,395 & 30,667 \\
\hline
\end{tabular}

The first line shows raw frequency number of vowels produced at each month. The second line shows the results of the proportion analysis of total production for a certain month of vowel (1-4\%: start level, 5-9\%: stability level, $10 \%$ and over: familiarity level). The third line shows the results of the analysis by the percentage of infants out of total infants who produced a certain vowel more than three times (2549\%: emerging level, 50-74\%: acquisition level 1, 75\% and over: acquisition level 2)

Table 3. Production period of vowels by two analysis methods

\begin{tabular}{|c|c|c|c|c|c|c|}
\hline \multirow{2}{*}{$\begin{array}{c}\text { Age } \\
\text { (months) }\end{array}$} & \multicolumn{3}{|c|}{ Proportion for produced vowels } & \multicolumn{3}{|c|}{$\begin{array}{l}\text { Percentage of infants who produced } \\
\text { a certain vowel }\end{array}$} \\
\hline & $\begin{array}{c}\text { Start } \\
(1-4 \%) \\
\end{array}$ & $\begin{array}{l}\text { Stability } \\
(5-9 \%) \\
\end{array}$ & $\begin{array}{c}\text { Famility } \\
(10 \% \text { and over })\end{array}$ & $\begin{array}{l}\text { Emerging } \\
(25-50 \%) \\
\end{array}$ & $\begin{array}{c}\text { Acquisition } 1 \\
(50-74 \%) \\
\end{array}$ & $\begin{array}{c}\text { Acquisition } 2 \\
\text { (75\% and over) }\end{array}$ \\
\hline $1-3$ & / ト/, / ㅔㅔ ( H)/, I_/ & & & & / ト/, / H ( H)/ & \\
\hline $4-5$ & $/ k /, /+1, / \mathrm{T} /, / \mid /$ & / N ( H $) /, /$ L I & & $1+1,11 /$ & 1-1 & \\
\hline $6-7$ & /기(개,게)/ & $1+1$ & & & & / ト I, I-1 \\
\hline $8-9$ & /TA/, /T/, /T/ & & & & & \\
\hline $10-11$ & /月/,/ㄱ/,/과/,/ㅛㅛ/ & $1+1$ & & & & \\
\hline $12-13$ & / \# $($ 月 $) /, /$-l/ & 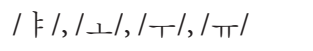 & & $|T|$ & $1+1,11 /$ & \\
\hline $14-15$ & & /月/ & & / F/ & & / H ( H )/ \\
\hline $16-17$ & & /사/ & & /ユ/ & $|T|$ & \\
\hline $18-19$ & & 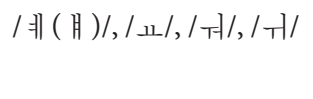 & 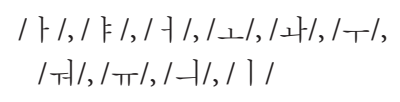 & & & $1+1,11 /$ \\
\hline $20-21$ & & & 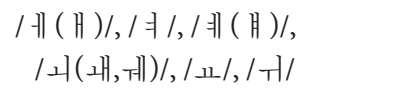 & & |/ & \\
\hline $22-24$ & & & 1 -1 & /키, /표/ & / $/$ & // \\
\hline
\end{tabular}

발성해야 하는 원순모음에 비해 입술을 평평하게 하여 발음하 는 평순모음을 더 많이 산출하였다.

두 가지 방법으로 분석한 단계별 모음의 산출시기는 Table 3 과 같다. 두 분석 방법 간 단계별 산출 시기에는 다소 차이가 있 었지만, 두 분석 방법에서 공통적으로 / / /, / / ( (H)/, / / / 가 가장 먼저 나타나는 음소로 적어도 1 3개월에 시작단계에 포함되었 고, 이는 출현단계를 거치지 않고 4 5개월에 습득 1단계에 도 달하는 것으로 나타났다. 17개 모음이 모두 18 24개월에 친숙 단계에 도달하였고, 6개 모음 / / /, / _/, / / (H)/,/ //, / //, / / /만 이 습득 2 단계에 도달하였다. 두 분석 방법에서 공통적으로 산출량과 시기 모두 혀의 위치에 따른 분류로 살펴보았을 때

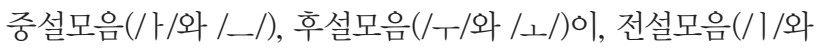
$/$ 기/) 순으로 발달하는 것으로 나타났다.

\section{초성자음 분석}

초성자음을 총 13,195 개로 분석한 결과를 월령구간별로 산 출 빈도 및 비율을 분석하여 Table 4에 제시하였다. 초성자음 은 4개월부터 산출되었다. 초성자음의 산출시기와 영아의 성장 에 따른 산출 빈도 및 비율의 변화를 확인하기 위하여 해당 음 소의 총 산출 비율을 이용한 분석 방법에 따라 1 24개월의 산 출량 중 한 월령구간의 산출량이 차지하는 비율을 분석하였다. 예를 들어, /ㅁㅇㅢ 경우 전 월령구간에서 산출된 /ㅁㅇㅢ 총 산출 량 2,069개 중 4 5개월의 /ㅁ/ 산출량은 35개로, 0.02 즉, $2 \%$ 의 산출률을 나타내었다. 초성자음의 산출 시기를 분석하기 위하 여 해당 음소를 산출한 인원의 비율을 이용한 분석 방법에 따 라 분석하였을 때, 4 5개월에 출현단계로 나타난 초성자음은 /ㅁ/(30\%)이었다. 8 9개월에 출현단계에 도달한 음소는 /ㅂ/ (44\%)이었다. 10 11개월에는 /ᄀᄀ/(35\%)과 /ᄃ/(31\%)이 출현단계 
Table 4. The raw frequency number, the portion of the production, and the percentage of infants who produced a certain initial consonant for each month

\begin{tabular}{|c|c|c|c|c|c|c|c|c|c|c|c|}
\hline \multirow{2}{*}{$\begin{array}{c}\text { Initial } \\
\text { consonants }\end{array}$} & \multicolumn{10}{|c|}{ Age (months) } & \multirow{2}{*}{ Total } \\
\hline & $4-5$ & $6-7$ & $8-9$ & $10-11$ & $12-13$ & $14-15$ & $16-17$ & $18-19$ & $20-21$ & $22-24$ & \\
\hline \multirow[t]{3}{*}{$\neg$} & 52 & 47 & 55 & 99 & 206 & 143 & 117 & 148 & 268 & 389 & 1,556 \\
\hline & $(0.03)$ & $(0.03)$ & $(0.04)$ & $(0.06)$ & $(0.13)$ & $(0.09)$ & $(0.08)$ & $(0.10)$ & $(0.17)$ & $(0.25)$ & \\
\hline & $22 \%$ & $12 \%$ & $17 \%$ & $35 \%$ & $30 \%$ & $45 \%$ & $65 \%$ & $55 \%$ & $64 \%$ & $80 \%$ & \\
\hline \multirow[t]{3}{*}{$\pi$} & 1 & 16 & 7 & 48 & 108 & 96 & 32 & 85 & 169 & 449 & 1,013 \\
\hline & $(0.00)$ & $(0.02)$ & $(0.01)$ & $(0.05)$ & $(0.11)$ & $(0.09)$ & $(0.03)$ & $(0.08)$ & $(0.17)$ & $(0.44)$ & \\
\hline & $0 \%$ & $3 \%$ & $0 \%$ & $19 \%$ & $21 \%$ & $38 \%$ & $41 \%$ & $35 \%$ & $42 \%$ & $60 \%$ & \\
\hline \multirow[t]{3}{*}{ ᄂ } & 10 & 10 & 27 & 20 & 120 & 164 & 107 & 181 & 190 & 407 & 1,241 \\
\hline & $(0.01)$ & $(0.01)$ & $(0.02)$ & $(0.02)$ & $(0.10)$ & $(0.13)$ & $(0.09)$ & $(0.15)$ & $(0.15)$ & $(0.33)$ & \\
\hline & $9 \%$ & $3 \%$ & $8 \%$ & $15 \%$ & $24 \%$ & $34 \%$ & $35 \%$ & $39 \%$ & $52 \%$ & $80 \%$ & \\
\hline \multirow[t]{3}{*}{ ᄃ } & 1 & 10 & 28 & 72 & 103 & 113 & 44 & 106 & 268 & 400 & 1,147 \\
\hline & $(0.00)$ & $(0.01)$ & $(0.02)$ & $(0.06)$ & $(0.09)$ & $(0.10)$ & $(0.04)$ & $(0.09)$ & $(0.23)$ & $(0.35)$ & \\
\hline & $0 \%$ & $3 \%$ & $8 \%$ & $31 \%$ & $30 \%$ & $52 \%$ & $41 \%$ & $45 \%$ & $67 \%$ & $77 \%$ & \\
\hline \multirow[t]{3}{*}{ 匹 } & 0 & 1 & 3 & 21 & 108 & 72 & 48 & 204 & 291 & 399 & 1,147 \\
\hline & & $(0.00)$ & $(0.00)$ & $(0.02)$ & $(0.09)$ & $(0.06)$ & $(0.04)$ & $(0.18)$ & $(0.25)$ & $(0.35)$ & \\
\hline & & $0 \%$ & $0 \%$ & $8 \%$ & $15 \%$ & $38 \%$ & $35 \%$ & $68 \%$ & $52 \%$ & $71 \%$ & \\
\hline \multirow[t]{3}{*}{ ᄅ } & 3 & 0 & 10 & 15 & 9 & 28 & 8 & 24 & 34 & 74 & 205 \\
\hline & $(0.01)$ & & $(0.05)$ & $(0.07)$ & $(0.04)$ & $(0.14)$ & $(0.04)$ & $(0.12)$ & $(0.17)$ & $(0.36)$ & \\
\hline & $4 \%$ & & $6 \%$ & $4 \%$ & $3 \%$ & $21 \%$ & $18 \%$ & $10 \%$ & $18 \%$ & $40 \%$ & \\
\hline \multirow[t]{3}{*}{ ㅁ } & 35 & 108 & 245 & 154 & 205 & 343 & 78 & 215 & 215 & 468 & 2,069 \\
\hline & $(0.02)$ & $(0.05)$ & $(0.12)$ & $(0.07)$ & $(0.10)$ & $(0.17)$ & $(0.04)$ & $(0.10)$ & $(0.10)$ & $(0.23)$ & \\
\hline & $30 \%$ & $30 \%$ & $36 \%$ & $50 \%$ & $48 \%$ & $66 \%$ & $53 \%$ & $71 \%$ & $61 \%$ & $86 \%$ & \\
\hline \multirow[t]{3}{*}{ ᄇ } & 29 & 187 & 371 & 63 & 89 & 97 & 53 & 112 & 188 & 203 & 1,395 \\
\hline & $(0.02)$ & $(0.13)$ & $(0.27)$ & $(0.05)$ & $(0.06)$ & $(0.07)$ & $(0.04)$ & $(0.08)$ & $(0.13)$ & $(0.15)$ & \\
\hline & $13 \%$ & $24 \%$ & $44 \%$ & $27 \%$ & $36 \%$ & $45 \%$ & $59 \%$ & $52 \%$ & $58 \%$ & $71 \%$ & \\
\hline \multirow[t]{3}{*}{ 뿌 } & 1 & 1 & 54 & 47 & 48 & 109 & 65 & 204 & 284 & 252 & 1,065 \\
\hline & $(0.00)$ & $(0.00)$ & $(0.05)$ & $(0.04)$ & $(0.05)$ & $(0.10)$ & $(0.06)$ & $(0.19)$ & $(0.27)$ & $(0.24)$ & \\
\hline & $0 \%$ & $0 \%$ & $14 \%$ & $15 \%$ & $12 \%$ & $38 \%$ & $53 \%$ & $48 \%$ & $52 \%$ & $69 \%$ & \\
\hline \multirow[t]{3}{*}{ 人 } & 0 & 0 & 1 & 6 & 12 & 13 & 2 & 31 & 47 & 64 & 176 \\
\hline & & & $(0.01)$ & $(0.03)$ & $(0.07)$ & $(0.07)$ & $(0.01)$ & $(0.18)$ & $(0.27)$ & $(0.36)$ & \\
\hline & & & $0 \%$ & $4 \%$ & $6 \%$ & $3 \%$ & $6 \%$ & $19 \%$ & $21 \%$ & $37 \%$ & \\
\hline \multirow[t]{3}{*}{ 从 } & 0 & 0 & 0 & 0 & 1 & 1 & 1 & 4 & 17 & 10 & 34 \\
\hline & & & & & $(0.03)$ & $(0.03)$ & $(0.03)$ & $(0.12)$ & $(0.50)$ & $(0.29)$ & \\
\hline & & & & & $0 \%$ & $0 \%$ & $0 \%$ & $3 \%$ & $3 \%$ & $9 \%$ & \\
\hline \multirow[t]{3}{*}{ x } & 0 & 0 & 3 & 5 & 9 & 33 & 21 & 50 & 81 & 218 & 420 \\
\hline & & & $(0.01)$ & $(0.01)$ & $(0.02)$ & $(0.08)$ & $(0.05)$ & $(0.12)$ & $(0.19)$ & $(0.52)$ & \\
\hline & & & $3 \%$ & $0 \%$ & $3 \%$ & $17 \%$ & $24 \%$ & $32 \%$ & $39 \%$ & $63 \%$ & \\
\hline \multirow[t]{3}{*}{ 从 } & 0 & 0 & 0 & 0 & 20 & 10 & 10 & 36 & 101 & 96 & 273 \\
\hline & & & & & $(0.07)$ & $(0.04)$ & $(0.04)$ & $(0.13)$ & $(0.37)$ & $(0.35)$ & \\
\hline & & & & & $6 \%$ & $3 \%$ & $6 \%$ & $19 \%$ & $24 \%$ & $37 \%$ & \\
\hline \multirow[t]{3}{*}{ 之 } & 0 & 0 & 1 & 6 & 11 & 21 & 3 & 48 & 72 & 72 & 234 \\
\hline & & & $(0.00)$ & $(0.03)$ & $(0.05)$ & $(0.09)$ & $(0.01)$ & $(0.21)$ & $(0.31)$ & $(0.31)$ & \\
\hline & & & $0 \%$ & $4 \%$ & $3 \%$ & $7 \%$ & $0 \%$ & $19 \%$ & $24 \%$ & $34 \%$ & \\
\hline \multirow[t]{3}{*}{$\Rightarrow$} & 1 & 1 & 9 & 6 & 14 & 7 & 10 & 12 & 35 & 87 & 183 \\
\hline & $(0.01)$ & $(0.01)$ & $(0.05)$ & $(0.03)$ & $(0.08)$ & $(0.04)$ & $(0.05)$ & $(0.07)$ & $(0.19)$ & $(0.48)$ & \\
\hline & $0 \%$ & $0 \%$ & $6 \%$ & $8 \%$ & $6 \%$ & $3 \%$ & $12 \%$ & $10 \%$ & $24 \%$ & $40 \%$ & \\
\hline
\end{tabular}


Table 4. The raw frequency number, the portion of the production, and the percentage of infants who produced a certain initial consonant for each month (continued)

\begin{tabular}{|c|c|c|c|c|c|c|c|c|c|c|c|}
\hline \multirow{2}{*}{$\begin{array}{c}\text { Initial } \\
\text { consonants }\end{array}$} & \multicolumn{10}{|c|}{ Age (months) } & \multirow{2}{*}{ Total } \\
\hline & $4-5$ & $6-7$ & $8-9$ & $10-11$ & $12-13$ & $14-15$ & $16-17$ & $18-19$ & $20-21$ & $22-24$ & \\
\hline \multirow[t]{3}{*}{$E$} & 2 & 4 & 9 & 3 & 21 & 24 & 8 & 21 & 11 & 105 & 208 \\
\hline & $(0.01)$ & $(0.02)$ & $(0.04)$ & $(0.01)$ & $(0.10)$ & $(0.12)$ & $(0.04)$ & $(0.10)$ & $(0.05)$ & $(0.50)$ & \\
\hline & $0 \%$ & $3 \%$ & $3 \%$ & $0 \%$ & $6 \%$ & $7 \%$ & $12 \%$ & $10 \%$ & $9 \%$ & $43 \%$ & \\
\hline \multirow[t]{3}{*}{ 표 } & 14 & 3 & 16 & 6 & 8 & 32 & 14 & 16 & 14 & 56 & 179 \\
\hline & $(0.08)$ & $(0.02)$ & $(0.09)$ & $(0.03)$ & $(0.04)$ & $(0.18)$ & $(0.08)$ & $(0.09)$ & $(0.08)$ & $(0.31)$ & \\
\hline & $4 \%$ & $0 \%$ & $6 \%$ & $4 \%$ & $3 \%$ & $7 \%$ & $12 \%$ & $6 \%$ & $9 \%$ & $29 \%$ & \\
\hline \multirow[t]{3}{*}{ क } & 35 & 46 & 52 & 32 & 66 & 78 & 47 & 51 & 101 & 190 & 704 \\
\hline & $(0.05)$ & $(0.07)$ & $(0.07)$ & $(0.05)$ & $(0.09)$ & $(0.11)$ & $(0.07)$ & $(0.07)$ & $(0.14)$ & $(0.27)$ & \\
\hline & $17 \%$ & $15 \%$ & $22 \%$ & $19 \%$ & $33 \%$ & $38 \%$ & $41 \%$ & $26 \%$ & $52 \%$ & $66 \%$ & \\
\hline
\end{tabular}

The first line shows raw frequency number of initial consonants produced at each month period. The second line shows the results of the proportion analysis of total production for a certain month period of initial consonant (1-4\%: start level, 5-9\%: stability level, $10 \%$ and over: familiarity level). The third line shows the results of the analysis by the percentage of infants out of total infants who produced a certain initial consonant more than three times (25-49\%: emerging level, 50-74\%: acquisition level 1, 75\% and over: acquisition level 2)

Table 5. Production period of initial consonants by two analysis methods

\begin{tabular}{|c|c|c|c|c|c|c|}
\hline \multirow{2}{*}{$\begin{array}{c}\text { Age } \\
\text { (months) }\end{array}$} & \multicolumn{3}{|c|}{ Proportion for produced initial consonant } & \multicolumn{3}{|c|}{$\begin{array}{c}\text { Percentage of infants who produced } \\
\text { a certain initial consonant }\end{array}$} \\
\hline & $\begin{array}{c}\text { Start } \\
(1-4 \%)\end{array}$ & $\begin{array}{l}\text { Stability } \\
(5-9 \%)\end{array}$ & $\begin{array}{c}\text { Famility } \\
(10 \% \text { and over })\end{array}$ & $\begin{array}{l}\text { Emerging } \\
(25-50 \%)\end{array}$ & $\begin{array}{l}\text { Acquisition } 1 \\
(50-74 \%)\end{array}$ & $\begin{array}{c}\text { Acquisition } 2 \\
\text { (75\% and over) }\end{array}$ \\
\hline $4-5$ & $\begin{array}{l}\text { /フ/,/レ/,/ロ/,//,/ヨ/, } \\
\text { /E/,/프/,/ᄒ/ }\end{array}$ & & & /ㅁ/ & & \\
\hline $6-7$ & /т/,/ㄷ/ & & & & & \\
\hline $8-9$ & /己/, / 昍/, /人/, /ス/ & & & /ㅂ/ & & \\
\hline $10-11$ & |匹/,/え/ & /ᄀ/,/т/,/ᄃ/ & & /ᄀ/,/ᄃ/ & /ㅁ/ & \\
\hline $12-13$ & & /ᄂ/, / 昍/, / 多/ & & |๘| & & \\
\hline $14-15$ & & |ス/, /프/ & & /ד/, / ᄂ/, /匹/, / 삐 / & & \\
\hline $16-17$ & & /ヨ/ & & & /ᄀ/, / / /, / / ㅂ/ & \\
\hline $18-19$ & & /E/ & 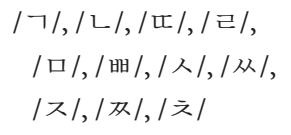 & |ス| & & \\
\hline $20-21$ & & & $\begin{array}{l}\text { /т/,/ᄃ/,/ㅂ/,/ヨ/, } \\
\text { // }\end{array}$ & & $\begin{array}{l}\text { /ᄂ/, /ᄃ/, /匹/, } \\
\text { /ᄒ/ }\end{array}$ & \\
\hline $22-24$ & & & /E/, /프/ & 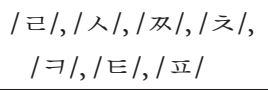 & | $\pi /, \mid$ ス & $\begin{array}{l}\text { /ᄀ/,/し/,/ᄃ/, } \\
\text { /ロ/ }\end{array}$ \\
\hline
\end{tabular}

에 도달하였고, /ㅁ/(50\%)은 습득 1단계에 도달하는 것으로 나 타났다. 12 13개월에는 /ᄒ/(33\%)이 출현단계에 도달하였고, 14 15개월에는 /T/(38\%), /ㄴ/(34\%), /匹/(38\%), /비/(38\%)이 출 현단계에 도달하였다. 16 17개월에는 / ᄀ/(67\%), /ㅂ/(59\%), /삐/ (53\%)이 습득 1단계에 도달하였다. 18 19개월에는 /ᄌ/(32\%)이 출현단계에 도달하였다. 20 21개월에는 /ㄴ/(52\%), /ㄷ/(67\%), $/$ 匹ᄄ/(52\%), //(52\%)이 습득 1단계에 도달하였다. 22 24개월에 는 /ㄹ/(40\%), / ㅅ/(37\%), / ㅉ/(37\%), /ᄎ/(34\%), / ᄏ/(40\%), /E/ (43\%), /프/(29\%)이 출현단계에 도달하였고, /7ᄁ/(60\%), /ㅈ/ (63\%)이 습득 1단계에 도달하였으며, /ᄀᄀ/(80\%), /ㄴ/(80\%), /ㄷ/ (77\%), /ㅁ/(86\%)이 습득 2단계에 도달하였다. 1 24개월에 출현
단계에 도달하지 않은 것으로 나타난 초성자음은/씨이었다. 해당음소의 총 산출 비율을 이용한 분석 방법을 사용하였을 때 4 5개월에 시작단계로 나타난 초성자음은 8개, / ᄀ/, / ᄂ/, /ㅁ/, /ㅂ/, /ㅋ/, /E/, /프/, /ㅎ/이고 출현단계는 1개, /ㅁ/ 뿐이었 다. 초성자음을 조음 위치에 따라 양순음(/ㅂ/, /ㅃ/, /프/), 치조 음(/ㄷ/, /匹/, /ㅌ/, /ㅅ/, /ㅆ/, /ㄴ/, /ㄹ/), 경구개음(/ㅈ/, /ㅉ/, /ㅊ/), 연구개음 $(/ \neg /, / \pi /, /$ / / $/)$, 성문음 $(/ \bar{\delta} /)$ 으로 분류하였을 때, 초 성자음이 나타나기 시작한 4개월에 연구개음인 /ㄱㄱㄱㅘ 양순음 /미이 가장 많이 산출되었으며, /ㄱㄱㄱㅘ /ㅁ은 16 17개월까지 가장 많이 산출된 상위 3 개의 초성자음에 포함되었다. 조음 방 법에 따라 파열음(/ᄀ/, /ㄲ/, /ㄱ/, /ᄃ/, /匹/, /ㅌ/, /ㅂ/, /ㅃ/, /프/), 
Table 6. The raw frequency number, the portion of the production, and the percentage of infants who produced a certain final consonants for each month

\begin{tabular}{|c|c|c|c|c|c|c|c|c|c|c|c|}
\hline \multirow{2}{*}{$\begin{array}{c}\text { Final } \\
\text { consonants }\end{array}$} & \multicolumn{10}{|c|}{ Age (months) } & \multirow{2}{*}{ Total } \\
\hline & $4-5$ & $6-7$ & $8-9$ & $10-11$ & $12-13$ & $14-15$ & $16-17$ & $18-19$ & $20-21$ & $22-24$ & \\
\hline \multirow[t]{3}{*}{$\neg$} & 2 & 0 & 2 & 10 & 4 & 7 & 22 & 8 & 26 & 50 & 131 \\
\hline & $(0.02)$ & & $(0.02)$ & $(0.08)$ & $(0.03)$ & $(0.05)$ & $(0.17)$ & $(0.06)$ & $(0.20)$ & $(0.38)$ & \\
\hline & $0 \%$ & & $0 \%$ & $0 \%$ & $3 \%$ & $0 \%$ & $12 \%$ & $3 \%$ & $15 \%$ & $23 \%$ & \\
\hline \multirow[t]{3}{*}{ ᄂ } & 0 & 1 & 4 & 3 & 19 & 56 & 17 & 66 & 77 & 103 & 46 \\
\hline & & $(0.00)$ & $(0.01)$ & $(0.01)$ & $(0.05)$ & $(0.16)$ & $(0.05)$ & $(0.19)$ & $(0.22)$ & $(0.30)$ & \\
\hline & & $0 \%$ & $0 \%$ & $0 \%$ & $3 \%$ & $0 \%$ & $12 \%$ & $3 \%$ & $15 \%$ & $23 \%$ & \\
\hline \multirow[t]{3}{*}{ ᄃ } & 0 & 1 & 0 & 0 & 5 & 4 & 5 & 9 & 23 & 40 & 87 \\
\hline & & $(0.01)$ & $(0.00)$ & $(0.00)$ & $(0.06)$ & $(0.05)$ & $(0.06)$ & $(0.10)$ & $(0.26)$ & $(0.46)$ & \\
\hline & & $0 \%$ & $0 \%$ & $4 \%$ & $3 \%$ & $0 \%$ & $12 \%$ & $6 \%$ & $15 \%$ & $26 \%$ & \\
\hline \multirow[t]{3}{*}{ ᄅ } & 0 & 0 & 6 & 13 & 4 & 16 & 10 & 37 & 25 & 74 & 185 \\
\hline & & & $(0.03)$ & $(0.07)$ & $(0.02)$ & $(0.09)$ & $(0.05)$ & $(0.20)$ & $(0.14)$ & $(0.40)$ & \\
\hline & & & $3 \%$ & $0 \%$ & $0 \%$ & $7 \%$ & $18 \%$ & $13 \%$ & $12 \%$ & $40 \%$ & \\
\hline \multirow[t]{3}{*}{ ㅁ } & 16 & 41 & 154 & 91 & 164 & 143 & 50 & 117 & 154 & 173 & 1,103 \\
\hline & $(0.01)$ & $(0.04)$ & $(0.14)$ & $(0.08)$ & $(0.15)$ & $(0.13)$ & $(0.05)$ & $(0.11)$ & $(0.14)$ & $(0.16)$ & \\
\hline & $4 \%$ & $12 \%$ & $28 \%$ & $23 \%$ & $39 \%$ & $48 \%$ & $35 \%$ & $35 \%$ & $48 \%$ & $60 \%$ & \\
\hline \multirow[t]{3}{*}{ ㅂ } & 0 & 0 & 16 & 10 & 4 & 9 & 5 & 8 & 25 & 47 & 124 \\
\hline & & & $(0.13)$ & $(0.08)$ & $(0.03)$ & $(0.07)$ & $(0.04)$ & $(0.06)$ & $(0.20)$ & $(0.38)$ & \\
\hline & & & $0 \%$ & $6 \%$ & $8 \%$ & $7 \%$ & $0 \%$ & $3 \%$ & $15 \%$ & $26 \%$ & \\
\hline \multirow[t]{3}{*}{0} & 50 & 46 & 26 & 42 & 92 & 169 & 117 & 297 & 314 & 695 & 1,848 \\
\hline & $(0.03)$ & $(0.02)$ & $(0.01)$ & $(0.02)$ & $(0.05)$ & $(0.09)$ & $(0.06)$ & $(0.16)$ & $(0.17)$ & $(0.38)$ & \\
\hline & $26 \%$ & $15 \%$ & $19 \%$ & $12 \%$ & $27 \%$ & $21 \%$ & $53 \%$ & $71 \%$ & $55 \%$ & $83 \%$ & \\
\hline
\end{tabular}

The first line shows raw frequency number of final consonants produced at each month. The second line shows the results of the proportion analysis of total production for a certain month of final consonant (1-4\%: start level, 5-9\%: stability level, $10 \%$ and over: familiarity level). The third line shows the results of the analysis by the percentage of infants out of total infants who produced a certain final consonant more than three times (25-49\%: emerging level, 50-74\%: acquisition level 1, 75\% and over: acquisition level 2)

Table 7. Production period of final consonants by two analysis methods

\begin{tabular}{|c|c|c|c|c|c|c|}
\hline \multirow{2}{*}{$\begin{array}{c}\text { Age } \\
\text { (months) }\end{array}$} & \multicolumn{3}{|c|}{ Proportion for produced final consonant } & \multicolumn{3}{|c|}{$\begin{array}{c}\text { Percentage of infants who produced } \\
\text { a certain final consonant }\end{array}$} \\
\hline & $\begin{array}{c}\text { Start } \\
(1-4 \%)\end{array}$ & $\begin{array}{l}\text { Stability } \\
(5-9 \%)\end{array}$ & $\begin{array}{c}\text { Famility } \\
(10 \% \text { and over })\end{array}$ & $\begin{array}{l}\text { Emerging } \\
(25-50 \%)\end{array}$ & $\begin{array}{c}\text { Acquisition } 1 \\
(50-74 \%)\end{array}$ & $\begin{array}{c}\text { Acquisition } 2 \\
\text { (75\% and over) }\end{array}$ \\
\hline $4-5$ & /ㅁ/,/O/ & & & & & \\
\hline $6-7$ & & & & & & \\
\hline $8-9$ & /フ/, / ᄂ/, /己/ & /ㅁ/ & & /ロ/ & & \\
\hline $10-11$ & & & & & & \\
\hline $12-13$ & & /レ/, /ᄃ/,/O/ & & 101 & & \\
\hline $14-15$ & & /ᄀ/,/己/ & & & & \\
\hline $16-17$ & & & & & 101 & \\
\hline $18-19$ & & /ㅂ / & /レ/,/ᄃ/,/己/,/ロ/,/O/ & & & \\
\hline $20-21$ & & & /ᄀ/,/日/ & & & \\
\hline $22-24$ & & & & /ᄃ/,/己/,/日/ & /미 & 101 \\
\hline
\end{tabular}

파찰음(/ㅈ/, /ㅉ/, /ㅊ/), 마찰음(/ㅅ/, /ㅆ/, /ㅎ/), 비음(/ᄂ/, /ㅁ/), 유음(/2ᄅ/)으로 분류하여 분석하였을 때, 비음인 /ㅁ/이 전체 월 령구간에서 가장 많이 나타났고, 파열음인 /ㄱ/이 그 뒤를 이었 다. 파열음 중 /ᄀ/, / T//, /ᄃ/, /匹/, /ㅂ/, /ㅃ/이 전체 월령구간을 통해서 많이 산출된 음소로 분석되었다.
두 가지 방법으로 분석한 단계별 초성자음의 산출시기는 Table 5와 같다. 두 분석 방법 간 단계별 산출 시기에는 다소 차 이가 있었지만, 두 분석 방법에서 공통적으로 / ᄀ//, /ㅁ/, /ㅂ/, /디이 가장 먼저 나타나는 음소로 적어도 6 7개월에 시작단계 에 포함되었고, 10 11개월까지 출현단계에 포함되었다. 18개 초 
성자음이 모두 18 24개월에 친숙단계에 도달하였고, 4개 초성 자음 / ᄀ/, /ㄴ/, /ㄷ/, /ㅁ만이 습득 2단계에 도달하였다. 조음 위치에 따른 분류에서 경구개음인 / $\pi /$ 과 / $/$ /이 늦게 나타났고, 조음 방법에 따른 분류에서 파찰음인 / ㅈ/, /ㅉ/, /ㅊ/과 유음인 /리이 늦게 나타나는 특성을 보였다.

\section{종성자음 분석}

종성자음을 총 3,824 개로 분석한 결과를 월령구간별로 산출 빈도 및 비율을 분석하여 Table 6에 제시하였다. 종성자음의 산출시기와 영아의 성장에 따른 산출 빈도 및 비율의 변화를 확인하기 위하여 해당 음소의 총 산출 비율을 이용한 분석 방 법에 따라 1 24개월의 산출량 중 한 월령구간의 산출량이 차 지하는 비율을 분석하였다. 예를 들어, $/ 0 /$ 의 경우 전 월령구간 에서 산출된 / $/ 0 /$ 의 총 산출량 1,848 개 중 4 5개월의 /O/ 산출 량은 50 개로, 0.03 즉, $3 \%$ 의 산출률을 나타내었다. 종성자음의 산출 시기를 분석하기 위하여 해당 음소를 산출한 인원의 비 율을 이용한 분석 방법에 따라 분석하였을 때, 8 9개월에 출현 단계에 도달한 종성자음은 /ㅁ/(28\%)이었고, 12 13개월에 출현 단계에 도달한 모음은 $/ 0 /(27 \%)$ 이었다. 16 17개월에 습득 1단 계에 도달한 모음은 $/ 0 /(53 \%)$ 이었다. 22 24개월에는 /ㄷ/ (26\%), /ㄹ/(40\%), /ㅂ/(26\%)이 출현단계에 도달하였고, /ㅁ/ $(60 \%)$ 이 습득 1단계에 도달하였으며, /0/(83\%)이 습득 2단계에 도달하였다. 1 24개월에 출현단계에 도달하지 않은 것으로 나 타난 종성자음은 / ᄀ/과 / ㄴ/이었다. 해당음소의 총 산출 비율 을 이용한 분석 방법을 사용하였을 때 4 5개월에 시작단계로 나타난 종성자음은 2개로 /ㅁ/과 / $/$ /이고 해당음소를 산출한 인원의 비율을 이용한 분석 방법을 사용하였을 때 출현단계로 나타난 종성자음은 없었고, 8 9개월이 되어서야/ㅁㅇㅣ 출현단 계에 도달한 것으로 나타났다.

두 가지 방법으로 분석한 단계별 종성자음의 산출시기는 Table 7과 같다. 두 분석 방법 간 단계별 산출 시기에는 다소 차 이가 있었지만, 두 분석 방법에서 공통적으로 /ㅁㄱㄱㅘ / $0 /$ 이 가 장 먼저 나타나는 음소로 적어도 4 5개월에 시작단계에 포함 되었고, 12 13개월에 출현단계에 포함되었다. 17개 종성자음이 모두 18 24개월에 친숙단계에 도달하였고, 6개 종성자음 /0/ 만이 습득 2 단계에 도달하였다. 두 분석 방법에서 공통적으로 조음 위치에 따른 분류로 보았을 때 양순음인 /ㅁㄱㄱㅘ 연구개음 인 / $/$ /이 가장 먼저 나타났다.

위 분석된 내용을 바탕으로 KIVAD 리스트를 구성하였다. KIVAD 리스트는 월령구간별 발성 및 조음발달의 기준을 제 시한 표로, 발성 영역과 조음 영역으로 구분하였고, 조음의 경 우 모음, 초성자음, 종성자음으로 분류하였다. 발성 영역의 경 우 ‘KIVAD_V'로 제시하였으며, 영아가 성장함에 따라 산출되
고 소멸되는 발성유형이 있어, 최대 산출비율을 나타낸 이후, $1 \%$ 이하의 발성율이 연속 3 번 나타나면 소멸되는 것으로 간주 하였다. 조음 영역의 경우, '해당 음소의 총 산출 비율을 이용한 분석'에 따른 목록과 ‘해당 음소를 산출한 인원의 비율을 이용 한 분석'에 따른 목록 두 개를 모두 제시하였다. '해당 음소의 총 산출 비율을 이용한 분석'에 따른 목록을 'KIVAD_AA'로 제시하였으며 KIVAD_AA에는 3개의 월령구간에서 연속으로 $1 \%$ 이상 관찰된 시작 구간과 3 개의 월령구간에서 연속으로 $5 \%$ 이상 관찰된 안정 구간, $10 \%$ 이상 관찰되는 친숙구간으로 표기하여 해당 조음의 산출시기를 확인할 수 있도록 하였다. '해당 음소를 산출한 인원의 비율을 이용한 분석'에 따른 목록 을 'KIVAD_AB'로 제시하였고 KIVAD_AB에는 출현단계(25 49\%), 습득 1단계(50 74\%), 습득 2단계(75\% 이상)로 구분하여 해당 조음의 산출시기를 확인할 수 있도록 하였다. 대상이 영아 인 점을 고려하여 부모가 쉽고 간단하게 체크할 수 있도록 해당 조음을 잘 말할 수 있다면 '예(O)', 가끔 말한 적이 있다면 '가끔 $(\triangle)$ ', '전혀 말한 적이 없다면 '아니오 $(X)$ '로 표기하도록 하였다 (Appendix 2 4).

\section{DISCUSSIONS}

1 24개월 영아의 발성발달은 월령이 증가함에 따라 VEG, $\mathrm{CR}, \mathrm{Q}, \mathrm{Q} 2, \mathrm{~F}, \mathrm{~F} 2$ 등 초기단계의 발성이 줄어들고, $\mathrm{CV}, \mathrm{CVCV}$, $\mathrm{CMPX}, / \mathrm{y} /$ 등의 상위단계 발성이 많이 나타났다. 이는 선행연 구(Kim, 2015; Nathani et al., 2006)와 일치하는 결과이다. 또 한 영아는 월령이 증가함에 따라 어음 같지 않은 소리의 비율 이 점차 줄어들고, 전 월령구간에서 모음산출이 가장 우세한 발성 유형으로 나타났다. 이는 국내외의 선행연구(Kim et al., 2015; Nathani et al., 2006) 결과와 일치하며, 이로 인해 월령 구간에 따른 유의미한 차이를 보이지 않았다. 이 외에 유의미 한 차이를 보이지 않은 발성 유형으로는 $\mathrm{cv}, \mathrm{cv} 2, \mathrm{~V}, \mathrm{~V} 2, \mathrm{Vg}$, $\mathrm{IN}, \mathrm{SQ}, \mathrm{MB}, \mathrm{CB}, \mathrm{CV}-\mathrm{C}$ 가 있었다. 이러한 종류는 전 월령구간 에 걸쳐 꾸준히 산출되는 발성유형이거나 발성수가 다른 발성 유형에 비해 비교적 적은 발성유형이었다. Nathani et al.(2006) 은 영어가 모국어인 9 15개월 영아가 주로 4단계 발성을 나타 낸다고 보고하였는데, 본 연구에서는 4단계 발성에 해당하는 CVCV는 10 11개월부터 가장 많이 나타난 상위 3개의 발성유 형에 포함되었고, 5 단계의 발성에 해당하는 CMPX는 12 13개 월부터 가장 많이 나타난 상위 3 개의 발성유형에 포함되어, 국 내 영아가 국외 영아보다 상위 발성유형을 비교적 빨리 산출하 는 것으로 나타났다. 이는 국내 선행연구와 일치하는 결과이며, 이에 대해 Ha et al.(2014)은 한국 영아가 종성이나 다음절을 영 어권 영아보다 비교적 일찍 산출하기 때문이라고 보고하였다. 
모음은 3개월부터 산출되었으며, 3 24개월 월령구간에서 / / / 와 / / 가 전체 모음 산출 중 각각 $29 \%$ 로 가장 높은 비율을 차지하였다. 이는 1 18개월 영아를 대상으로 모음 발달 특성을 제시한 Kim et al.(2015)의 연구 결과 중 전 월령구간에서 / / / 가 가장 많이 산출되었다는 결과와 유사하다. 월령구간별로 살 펴보면, 1 3, 4 5, 6 7, 8 9, 10 11, 12 13개월은 / ///, /ㄱ(ㅐ)/, /_/가 가장 많이 나타났고, 14 15, 16 17, 18 19개월은 / / /, / / / / / / / 가 가장 많이 나타났다. 20 21개월은 / / /, / / / / / / 가 가장 많이 나타났고, 22 24개월은 / / /, / / /, / / / / / / 가 가장 많 이 나타났다. 1 36개월의 영아 86명을 대상으로 한국인의 의 사소통능력 발달단계에 관한 연구보고서에서 언어이전기의 말 소리 출현 양상을 분석한 Jong et al.(2005)에 의하면 6개월에 /F/, / / /, / / / / / _ / 의 네 가지 모음이 산출되기 시작하였으며, 월 령이 증가함에 따라 / / / 가 나타난다고 보고하였다. / / /, / / (H)/, / 가가 가장 먼저 산출된다는 점은 본 연구 결과와 동일하나, 본 연구에서는 1 3개월부터 / / /, / / (H)/, / _ / 가 산출되기 시작 하여 좀 더 빠른 산출 시기를 보였고, / / / 가 / / /, / / /, / / /, / _ / 산출 이후에 나타난다는 점은 동일하였다. 모음을 혀의 위치에 따라 분류하였을 때 중설모음, 전설모음, 후설모음 순으로 발성 발달 특성이 나타나는 것으로 분석할 수 있으며, 이중모음의 경 우, 초기 월령구간에는 나오지 않다가, 월령이 증가함에 따라 조 금씩 산출되기 시작하였다. 입술 모양에 따라 평순모음과 원순 모음으로 분류하여 분석하였을 때 영아는 입술을 동그랗게 말 아서 발성해야 하는 원순모음에 비해 입술을 평평하게 하여 발 음하는 평순모음을 더 많이 산출하였다. 산출시기를 해당음소 의 총 산출 비율을 이용한 분석 방법과 해당 음소를 산출한 인 원의 비율을 이용한 분석 방법을 사용하였을 때 모두 / / /, / -/, / / 개(H)/가 가장 빨리 출현하고 습득하는 것으로 나타났다. 이는 산출량이 많은 중설모음이며 평순모음에 해당하는 음소 로 나타났다. 이는 생후 1년 동안에는 저모음이자 비원순모음 인 모음을 선호한다는 Donegan(2002)의 보고와 일치한다.

초성 자음의 경우 4 개월부터 산출되었다. 조음 위치에 따른 분류로 살펴보면 양순음인 /ㅁㄱㅘㅘ 연구개음인 / ᄀ /을 가장 먼저 산출하기 시작하여, 16 17개월까지 가장 많이 산출된 상위 3개 의 자음 중 하나로 분류되었다. 조음 방법에 따른 분류로 살펴 보면, 파열음 $(/ \neg /, / \pi /, / ᄃ /, / 匹 /, / ㅂ /$, /ㅃ//)이 전체 월령구간을 통해 많이 나타났고, 비음(/ᄂ/과 /ㅁ/)이 그 뒤를 이었다. 해당 음소를 산출한 인원의 비율을 통한 분석을 하였을 때 사용한 습득 2단계의 기준인 75\%를 동일하게 사용한 2;0(2세 0개월)에 서 2;11(2세 11개월) 사이 /ㅂ/, /삐, /ㄷ/, /匹ᄄ/, /ㅌ/, /ㄴ/, /ᄀᄀ/, /T//, / ㅋ/, /피, /ㅁ/, / 이이 75\% 이상의 아동에게서 나타났다고 보고 하였다. 본 연구에서는 2세에 /ᄀ/, / ᄂ/, /ᄃ/, /ㅁ만이 75\% 이상 의 아동에게서 나타났다. Kim \& Stoel-Gammon(2000)에 의
하면, 2 세 6 개월에 $75 \%$ 아동이 습득한다고 보고하여 본 연구 에 비해 늦은 습득 연령을 보였다. 이러한 차이는 선행연구의 경우 2세 이상의 아동이 대상이었고, 유사 자모음을 제외하고 분석을 실시하여 대상 월령 및 분석 기준에서 발생된 차이로 생각된다.

종성 자음의 경우 해당 음소를 총 산출 비율을 이용하여 분 석하였을 때 4 5개월에 산출되기 시작하였고 해당 음소를 산 출한 인원의 비율을 이용하여 분석하였을 때 8 9개월부터 출 현단계에 이르는 것으로 나타났다. 1 24개월에 가장 많이 산출 되는 종성 자음으로는 연구개음인 / ㅇㄱㄱㅘ 양순음인 /ㅁ/이 해당 되었다.

조음의 산출 시기를 분석하기 위하여 두 가지 분석방법을 이 용하였을 때 분석 방법 간 공통점과 차이점이 확인되었다. 모음 의 경우 두 가지 분석 방법을 사용하였을 때 공통적으로 / / /, /게(H)/, / _ / 가 가장 먼저 출현하는 것으로 나타났다. 이는 산 출량이 많고 중설모음이며 평순모음에 해당하는 음소였다. 해 당 음소의 총 산출 비율을 이용한 분석 방법을 사용하였을 때 산출 시기가 더 빠른 것으로 나타났다. 예를 들어 // / 의 경우 해당 음소의 총 산출 비율을 이용한 분석을 하였을 때, $4 \sim 5$ 개 월에 시작 단계에 도달하였고 12 13개월에 안정단계에 도달하 는 것으로 분석되었으나 해당 음소를 산출한 인원의 비율을 이 용한 분석을 하였을 때, 14 15개월에 출현단계에 도달하였고 22 24개월이 되어서야 습득 1단계에 도달하였다. 또한 해당 음 소를 산출한 인원의 비율을 통한 분석을 하였을 때 아직 출현 하지 않은 것으로 나타난 /An(月)/, / 가/, / 기(개, 게)/, /거/, / 기/, / T/, / / / / 의 경우 해당 음소의 총 산출 비율을 이용한 분석에서 는 모두 24개월 미만에 산출이 이루어지는 것으로 분석되었다. 초성 자음의 경우, 두 가지 분석방법을 사용하였을 때 공통적 으로 /ᄀᄀ/, /ㅁ/, /ㅂ/ / / ㄷ/이 빨리 출현하는 것으로 나타났다. 초 음 위치에 따른 분류에서 경구개음이 늦게 나타나고 조음방법 에 따른 분류에서 파찰음과 유음이 늦게 나타나는 특성을 나 타내었다. 해당 음소의 총 산출 비율을 이용한 분석 방법을 사 용하였을 때 산출 시기가 더 빠른 것으로 나타났다. 예를 들어 초성 자음의 예를 살펴보면 /리의 경우 해당 음소의 총 산출 비율을 이용한 분석을 하였을 때 8 9개월에 시작단계에 도달 하였고 18 19개월에 안정단계에 도달하는 것으로 나타났으나 해당 음소를 산출한 인원의 비율을 이용한 분석을 하였을 때 22 24개월이 되어서야 출현단계에 도달하는 것으로 나타났다. 종성 자음의 경우 두 가지 분석방법을 사용하였을 때 공통적 으로 /ㅁㄱㅘ / / / 이 가장 먼저 출현하는 음소로 나타났다. 이는 전 월령구간에서 가장 높은 비율을 차지한 음소였다. 해당 음 소의 총 산출 비율을 이용한 분석 방법을 사용하였을 때 산출 시기가 더 빠른 것으로 나타났다. 예를 들어 /ㅁㅇㅢ 경우 해당 
음소의 총 산출 비율을 이용한 분석을 하였을 때 4 5개월에 시작 단계에 도달하고 8 9개월에 안정단계에 도달하는 것으로 나타났으나 해당 음소를 산출한 인원의 비율을 이용한 분석에 서는 8 9개월에 출현단계에 도달하였고 22 24개월이 되어서 야 습득 1단계에 도달하는 것으로 나타났다. 결론적으로 두 분 석 방법 간 산출 특성 및 순서는 유사하였으나 음소해당 음소 의 총 산출 비율을 이용한 분석 방법을 사용하였을 때 산출 시 기가 더 빠른 것으로 나타났다. 이러한 차이는 총 산출량 자체 가 적은 조음일수록 두드러졌다. 해당 음소의 총 산출 비율을 이용한 분석 방법의 경우 총 산출량을 이용하여 분석하므로 적 은 조음 산출량을 보여 해당 음소를 산출한 인원의 비율을 이 용한 분석으로 목록에서 제외되는 조음의 산출 특성을 관찰하 는데 용이했다. 그러나 월령구간별 인원 수가 최소 17 명에서 최 대 36 명으로 일정하지 않아 특정아동의 발성빈도가 매우 크거 나 작을 경우 총 산출량에 그대로 영향을 주어 이러한 부분이 차후 더 많은 자료의 수집으로 보완되기를 기대한다. 반면 해 당 음소를 산출한 인원의 비율을 이용한 분석 방법의 경우 3 번 이상 해당 발성 및 조음을 산출한 인원이 기준이므로, 특정 아 동의 산출 빈도가 매우 크더라도 산출빈도가 3 번 이상이기만 하면 1명으로 분석되기 때문에 개인차에서 오는 오류가 적었 다. 그러나 이러한 방법은 주로 12 24개월 이후의 성인과 같은 자모음을 조음하는 습득 시기를 파악하는 데 사용되는 방법이 므로(Kim, 1996; Kim \& Stoel-Gammon, 2010) 12개월 이전 영아의 조음 패턴을 분석하는 데 어려움이 있다. 따라서 12 개월 이전 언어 이전기 영아를 포함하고 언어 이전기의 초기 발성인 유사자모음도 함께 분석한 본 연구는 두 가지 방법으로 영아의 조음과정을 이해하도록 KIVAD리스트를 제시하였다. 해당 음 소의 총 산출 비율을 이용한 분석을 통해 제시된 KIVAD_AA 는 해당 음소의 총 산출량 중 월령구간별 산출량을 분석하여 초기 산출이 가능한 음소를 확인하는 데 더 유용하며, 월령이 증가함에 따라 나타나는 조음 산출과정을 확인하는데 용이하 도록 하였다. 해당 음소를 산출한 인원의 비율을 이용한 분석 으로 제시된 KIVAD_AB는 개인차에서 오는 변수를 줄일 수 있다는 장점이 있으나 초기 조음 능력을 분석할 수 없는 단점 이 있었다. 따라서 KIVAD_AA는 일반적으로 영아가 음소를 산출할 수 있을 정도로 인지가 완성된 월령구간을 이해할 수 있는 목록이고 $\mathrm{KIVAD} \mathrm{AB}$ 는 영아가 특정 조음을 완전히 산출 할 수 있는 단계를 관찰할 수 있는 목록이다. 결론적으로 청각장 애 영아의 경우 음소를 습득하여 산출하는 월령이 아닌, 음소를 산출하기 시작하는 능력이 있는 월령을 확인하여 청능재활로 해당음소를 목표로 설정하는 데 KIVAD_AA를 활용할 수 있을 것이고 부모가 영아의 산출 능력을 점검하는데 KIVAD_AB가 적절할 것으로 생각된다. 추후 데이터 수집을 추가적으로 실시
하여 24개월 이내의 완전한 자모음의 습득시기를 분석할 수 있 다면 초기 자모음 산출 및 습득 시기를 더욱 심층적으로 분석 할 수 있을 것으로 생각한다. 또한 본 연구에서는 횡-종단적 방 법을 사용하여 월령그룹별 모집인원과 모집 대상의 수가 달라 반복측정 및 다중비교 결과 대신 일원분석방법의 결과로 통계 적 유의미성을 제시하였다. 그러나 차후 월령구간별 인원이 더 확보되고 월령구간별 인원이 충분할 경우 반복측정이나 다중 비교가 더 필요할 것으로 생각된다.

중심 단어 : 영아·초기 발성 및 조음 발달· 국내 영아의 발성 및 조음 발달 목록.

\section{Acknowledgments}

본 연구는 2015년 대한민국 교육부와 한국연구재단의 중견연구 자 지원 사업(인문사회: H00159)지원을 받아 수행된 연구임(NRF2015S1A5A2A01011541).

\section{REFERENCES}

Davis, B. L. \& MacNeilage, P. F. (1995). The articulatory basis of babbling. Journal of Speech, Language, and Hearing Research, 38(6), 1199-1211.

Del Rey, A. S., Fernández, J. S., Ibarguen, A. M., \& Montoya, F. S. (1995). Morphologic and morphometric study of human spiral ganglion development. Acta Oto-Laryngologica, 115(2), 211-217.

Dodd, B., Holm, A., Hua, Z., \& Crosbie, S. (2003). Phonological development: A normative study of British English-speaking children. Clinical Linguistics and Phonetics, 17(8), 617-643.

Donegan, P. (2002). Normal vowel development. In M. J. Ball \& F. Gibbon. Vowel Disorders (pp. 1-35). Boston: Butterworth/Heinemann.

Grunwell, P. (1981). The development of phonology: A descriptive profile. First Language, 2(6), 161-191.

Ha, S. \& Park, B. (2015). Early vocalization and phonological developments of typically developing children: A longitudinal study. Journal of the Korean Society of Speech Sciences, 7(2), 63-73.

Ha, S., Seol, A., \& Pae, S. (2014). Vocal development of typically developing infants. Journal of the Korean Society of Speech Sciences, 6(4), 161169.

Houston, D. (2011). Infant speech perception. In R. Seewald \& A. M. Tharpe. Comprehensive Handbook of Pediatric Audiology (pp. 47-62). San Diego, CA: Plural Publishing.

Hua, Z. \& Dodd B. (2000). The phonological acquisition of Putonghua (modern standard Chinese). Journal of Child Language, 27(1), 3-42.

Jang, K. H., Kim, M. H., Lee, P. Y., Ahn, M. L., Kim, E. M., Cho, S. B., et al. (2005, January 31). A study of the development of conversation ability of Korean. Seoul: Hanyang University.

Kent, R. D. (1997). The Speech Sciences. San Diego, CA: Singular Publishing Group.

Kim, E., Kim, H., Song, H., Jun, Y., \& Choi, Y. (2012). ERP study to discriminate/1/-/r/. Korean Infants. Journal of Language Sciences, 19, 47-67.

Kim, J. S., Cho, E. B., Ma, S. M., Vark, Y. K., \& Yoon J. E. (2015). A study for development of vocal production in Korean normal hearing infants. Audiology, 11(4), 348-365.

Kim, M. \& Stoel-Gammon, C. (2010). Segmental timing of young children and adults. International Journal of Speech-Language Pathology, 12(3), 221-229.

Kim, Y. T. (1996). Correct consonants study of preschool children for picture consonant articulation test using. Communication Sciences and Disorders, 1, 7-34.

Kuhl, P. K. (2004). Early language acquisition: Cracking the speech code. 
Nature Reviews Neuroscience, 5(11), 831-843.

Liberman, A. M., Harris, K. S., Hoffman, H. S., \& Griffith, B. C. (1957). The discrimination of speech sounds within and across phoneme boundaries. Journal of Experimental Psychology, 54(5), 358-368.

McCune, L., Vihman, M. M., Roug-Hellichius, L., Delery, D. B., \& Gogate, L. (1996). Grunt communication in human infants (Homo sapiens). Journal of Comparative Psychology, 110(1), 27-36.

Moon, H. \& Ha, S. (2012). Phonological development in toddlers with cleft palate and typically developing toddlers aged 12-24 months. Communication Sciences and Disorders, 17(1), 118-129.

Nam, M., Cho, Y., Shin, M., Jeong, J., Yamane, N., \& Mazuka, R. (2015). Changes in the speech perception abilities among Korean infants during the first year of life: Discriminating lenis from aspirated stops. Paper presented at Korean Psychological Association Annual Conference. Seoul, Korea.

Nathani, S., Ertmer, D. J., \& Stark, R. E. (2006). Assessing vocal development in infants and toddlers. Clinical linguistics and Phonetics, 20(5), 351-369.

Oller, D. K. \& Yeni-Komshian, G. (1980). The emergence of the sounds of speech in infancy. Child Phonology, 1, 93-112.
Oller, D. K., Eilers, R. E., Basinger, D., Steffens, M. L., \& Urbano, R. (1995). Extreme poverty and the development of precursors to the speech capacity. First Language, 15(44), 167-187.

Piaget, J. (1952). The Origins of Intelligence in Children. New York, NY: International Universities Press.

Piaget, J. (1962). Play, Dreams and Imitation in Childhood. New York, NY: Norton.

Seok, D. I., Park, S. H., Shin, H. J., \& Park, J. H. (2002). A study on the development of Korean standard picture articulation test. Communication Sciences and Disorders, 7(3), 121-143.

Stark, R. E. \& Yeni-Komshian, G. (1980). Stages of speech development in the first year of life. Child Phonology, 1, 73-90.

Storkel, H. L. \& Morrisette, M. L. (2002). The lexicon and phonology interactions in language acquisition. Language, Speech, and Hearing Services in Schools, 33(1), 24-37.

Ttofari Eecen, K., Reilly, S., \& Eadie, P. (2007). Proceedings from Speech Pathology Australia National Conference: Parent concern and parent report of speech sound development at 12 months of age. Sydney, Australia. 


\section{APPENDICES}

Appendix 1. Vocalization Types Used for Analysis

\begin{tabular}{|c|c|}
\hline 발성 유형 & 의 \\
\hline 생리적인 소리(VEG) & 딸꾹질, 트림, 재채기, 기침 등 \\
\hline 울음(CR) & 울음소리, 칭얼거리는 소리, 짧게 보채는 소리 \\
\hline 불완전공명핵(Q) & 성인의 모음으로 설명할 수 없지만 모음같이 들리는 소리 \\
\hline 불완전공명핵2(O2) & 연속으로 발성되는 두 개 이상의 불완전공명핵(O) \\
\hline 완전공명핵(F) & $\mathrm{O}$ 보다는 더 모음 같은 소리(유사모음), 그러나 성인의 모음으로 분류하기는 어려운 소리 \\
\hline 완전공명핵2(F2) & 연속 발성되는 두 개 이상의 유사모음(F) \\
\hline 유사자모음(cv) & $\begin{array}{l}\text { 유사자음(자음 같은 소리)과 유사모음이 결합된 소리 } \\
\text { 그러나 성인의 자음과 모음으로 분류하기는 어려운 소리 }\end{array}$ \\
\hline 유사자모음2(cv2) & 연속으로 발성되는 두 개 이상의 유사자모음(cv) \\
\hline 웃음 $(\mathrm{CH})$ & 적어도 2번 이상 짧게 소리 내어 깔깔(혹은 껄껄)거리며 웃거나 계속 웃는 소리 \\
\hline 모음(V) & $\begin{array}{l}\text { 자음 없이 단독 산출된 모음 } \\
\text { 성인의 모음으로도 분류할 수 있을만큼 완전한 모음소리 }\end{array}$ \\
\hline 모음2(V2) & 연속 발성되는 두 개 이상의 모음(V) \\
\hline 모음성활음( $\mathrm{Vg})$ & $\begin{array}{l}\text { 이중모음(예: /요/, /야/, /와/ 등)이 나타나기 전의 발성으로, 모음의 변화가 있는 유사모음(F) } \\
\text { 예) 우아, 이아 }\end{array}$ \\
\hline 흡기음(IN) & 숨을 들이마시면서 나는 소리 \\
\hline 비명(SO) & 높은 주파수로 내지르는 비명소리 \\
\hline 유사옹알이(MB) & $\begin{array}{l}\text { 자음과 모음이 정확하지 않은 3글자 이상의 옹알이 } \\
\text { 예) 마마마, 으어아 }\end{array}$ \\
\hline 자모음단음절(CV) & 자음과 모음으로 구성되어 있는 한 글자의 발성 \\
\hline 음절성옹알이(CB) & $\begin{array}{l}\text { 자음과 모음으로 구성되어 있는 두 글자 이상의 옹알이 } \\
\text { 예) 마마마, 바비, 비다디 }\end{array}$ \\
\hline 속삭임(WH) & 속삭이는 소리 \\
\hline 자모음음절과 자음조합(CV-C) & $\begin{array}{l}\text { 자음과 모음으로 구성된 한 글자 발성 뒤에 자음이 뒤따르는 소리 } \\
\text { 예) 마-ㅂ, 바-ㅁ, 나-ㄱ }\end{array}$ \\
\hline 다음절(CVCV) & 자음과 모음으로 구성된 두 글자 이상의 발성 \\
\hline 응 & 긍정의 대답으로 사용되는 '응' \\
\hline 복합음절(CMPX) & $\begin{array}{l}\text { 다양한 자음과 모음으로 구성된 두 글자 이상의 발성 } \\
\text { 예) 아빠, 마나, 브다 }\end{array}$ \\
\hline 자곤(JN) & $\begin{array}{l}\text { 억양의 변화가 있는 뜻을 알 수 없는 말 같은 소리 } \\
\text { 예) 다다비 므나 }\end{array}$ \\
\hline 이중모음(DIP) & '요, 야, 와' 등의 이중모음 \\
\hline
\end{tabular}

VEG: vegetative, CR: crying sound, Q: quasi-resonant nuclei, Q2: quasi-resonant nuclei2, F: fully resonant nuclei, F2: fully resonant nuclei2, cv: consonant-like segment and vowel-like sound combination, cv2: consonant-like segment and vowel-like sound combination2, CH: chuckle, V: vowel, V2: vowel2, Vg: vowel Glide, IN: ingressive sound, SQ: squeal, MB: marginal babbling, CV: consonant-vowel, CB: canonical babbling, WH: whisper, CV-C: consonant-vowel combination, CVCV: disyllables, CMPX: complex syllables, JN: jargon, DIP: diphthongs 
Appendix 2. Korean Infant Vocal and Articulatory Development_Voclaization (KIVAD_V) List

\section{영유아의 발성발달(KIVAD_V) 목록}

\begin{tabular}{|ll|l|l|l|}
\hline 이 름 & 생 년 월 일 & \\
\hline 작 성 자 & 검 사 일 & \\
\hline
\end{tabular}

Korean Infant Vocalization and Articulation Development list (KIVAD)란 1 24개월 국내 영유아의 발성 및 조음 발달 내역 을 정리한 목록입니다. 아기들은 성장에 따라 특정 발성이나 조음이 각각 다를 수 있습니다. 해당 월령에서 아기가 발성이나 조 음이 조금 늦거나 빨리 나타나는 것은 흔히 있을 수 있는 일입니다. 아기가 아래의 발성을 했거나 잘 할 수 있다면 ' $\bigcirc$ ', 가끔 한 다면 ' $\triangle$ ', 전혀 못한다면 ' $X$ '로 체크 $(\vee)$ 해주세요.

\begin{tabular}{|c|c|c|c|c|c|c|c|c|c|c|c|}
\hline 발성 유형 & $1 \sim 3$ & $4 \sim 5$ & $6 \sim 7$ & $8 \sim 9$ & $10 \sim 11$ & $12 \sim 13$ & $14 \sim 15$ & $16 \sim 17$ & $18 \sim 19$ & $20 \sim 21$ & $22 \sim 24$ \\
\hline \multicolumn{12}{|l|}{ 생리적인 소리(VEG) } \\
\hline \multicolumn{12}{|l|}{ 울음(CR) } \\
\hline \multicolumn{12}{|l|}{ 불완전공명핵(Q) } \\
\hline \multicolumn{12}{|l|}{ 불완전공명핵2(O2) } \\
\hline \multicolumn{12}{|l|}{ 완전공명핵 F) } \\
\hline \multicolumn{12}{|l|}{ 완전공명핵(F2) } \\
\hline \multicolumn{12}{|l|}{ 유사자모음(cv) } \\
\hline \multicolumn{12}{|l|}{ 유사자모음2(cv2) } \\
\hline \multicolumn{12}{|l|}{ 웃음(CH) } \\
\hline \multicolumn{12}{|l|}{ 모음(V) } \\
\hline \multicolumn{12}{|l|}{ 모음2(V2) } \\
\hline \multicolumn{12}{|l|}{ 모음성활음(Vg) } \\
\hline \multicolumn{12}{|l|}{ 비명(SQ) } \\
\hline \multicolumn{12}{|l|}{ 유사옹알이(MB) } \\
\hline \multicolumn{12}{|l|}{ 자모음단음절(CV) } \\
\hline \multicolumn{12}{|l|}{ 음절성옹알이(CB) } \\
\hline \multicolumn{12}{|c|}{ 자모음 음절과 자음조합(CV-C) } \\
\hline \multicolumn{12}{|l|}{ 다음절(CVCV) } \\
\hline \multicolumn{12}{|l|}{ 복합음절(CMPX) } \\
\hline \multicolumn{12}{|l|}{ 자곤(JN) } \\
\hline \multicolumn{12}{|l|}{ 이중모음(DIP) } \\
\hline 응 & & & & & & & & & & & \\
\hline
\end{tabular}




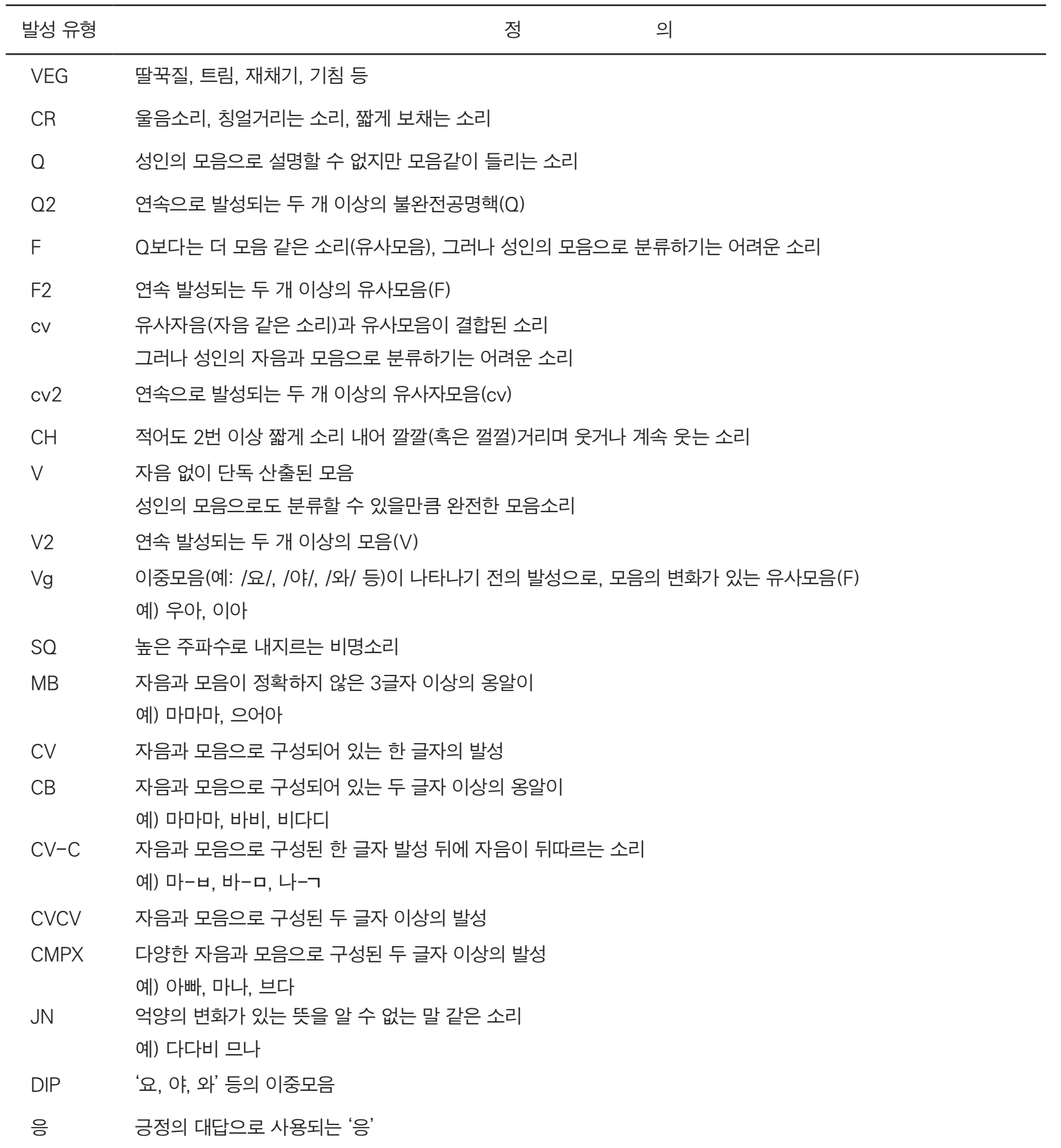

VEG: vegetative, CR: crying sound, Q: quasi-resonant nuclei, Q2: quasi-resonant nuclei2, F: fully resonant nuclei, F2: fully resonant nuclei2, cv: consonant-like segment and vowel-like sound combination, cv2: consonant-like segment and vowel-like sound combination2, CH: chuckle, V: vowel, V2: vowel2, Vg: vowel Glide, SO: squeal, MB: marginal babbling, CV: consonant-vowel, CB: canonical babbling, CV-C: consonant-vowel combination, CVCV: disyllables, CMPX: complex syllables, JN: jargon, DIP: diphthongs 
Appendix 3. Korean Infant Vocal and Articulatory Development_Ariticuation A (KIVAD_AA) List

\section{영유아의 조음발달(KIVAD_AA)목록}

\begin{tabular}{|ll|l|l|l|}
\hline 이 름 & 생 년 월 일 & \\
\hline 작 성 자 & & 검 사 일 & \\
\hline
\end{tabular}

Korean Infant Vocalization and Articulation Development list (KIVAD)란 1 24개월 국내 영유아의 발성 및 조음 발달 내역 을 정리한 목록입니다. 아기들은 성장에 따라 특정 발성이나 조음이 각각 다를 수 있습니다. 해당 월령에서 아기가 발성이나 조

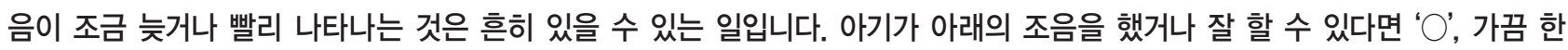
다면 ' $\triangle$ ', 전혀 못한다면 ' $\times$ '로 체크 $(\vee)$ 해주세요.
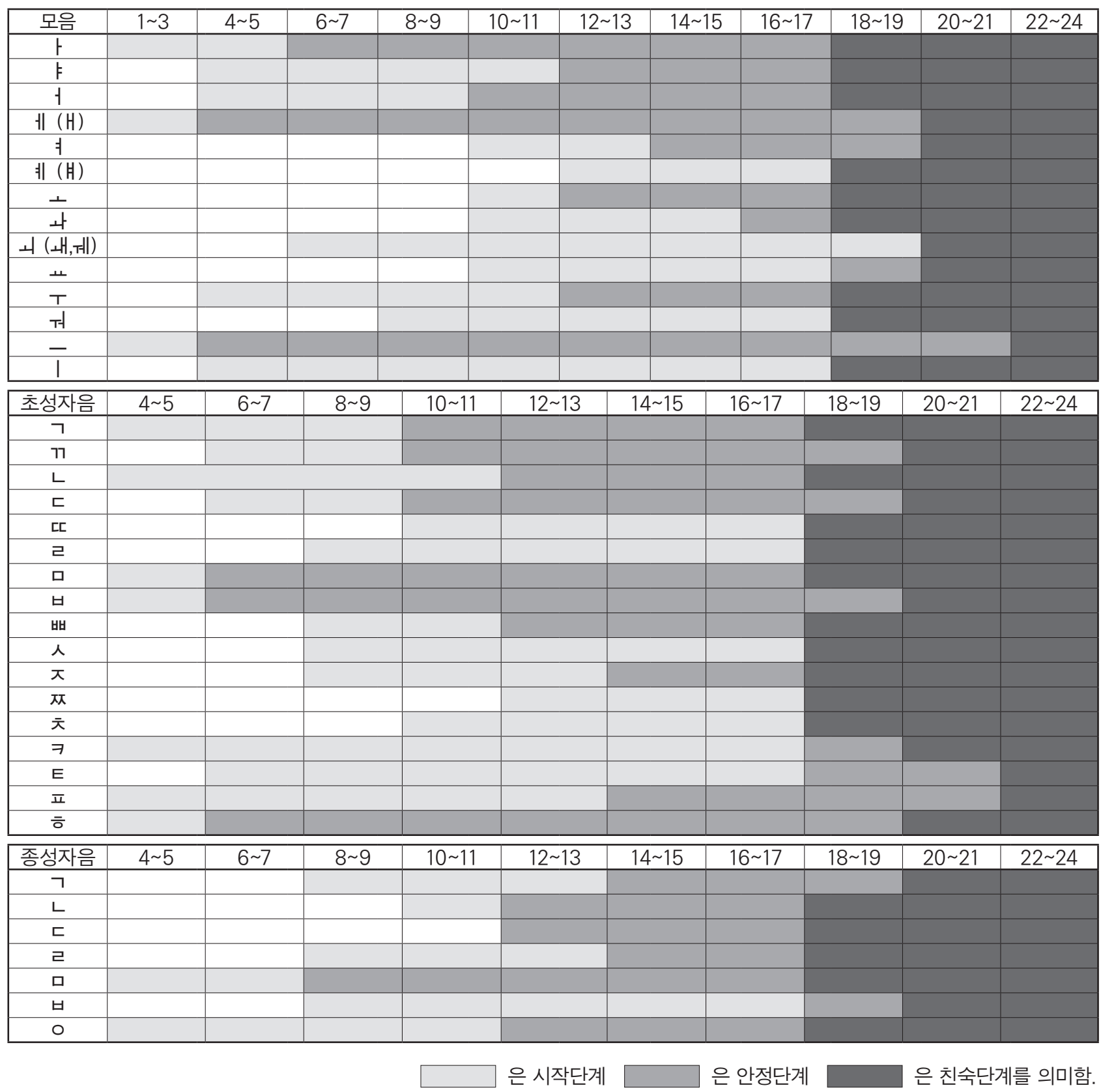
Appendix 4. Korean Infant Vocal and Articulatory Development_Articulation B (KIVAD_AB) List

\section{영유아의 조음발달(KIVAD_AB) 목록}

\begin{tabular}{|ll|l|l|l|}
\hline 이 름 & 생 년 월 일 & \\
\hline 작 성 자 & 검 사 일 & \\
\hline
\end{tabular}

Korean Infant Vocalization and Articulation Development list (KIVAD)란 1 24개월 국내 영유아의 발성 및 조음 발달 내역 을 정리한 목록입니다. 아기들은 성장에 따라 특정 발성이나 조음이 각각 다를 수 있습니다. 해당 월령에서 아기가 발성이나 조 음이 조금 늦거나 빨리 나타나는 것은 흔히 있을 수 있는 일입니다. 아기가 아래의 조음을 했거나 잘 할 수 있다면 ' $\bigcirc$ ', 가끔 한 다면 ' $\triangle$ ', 전혀 못한다면 ' $\times$ '로 체크( $\vee$ 해주세요.
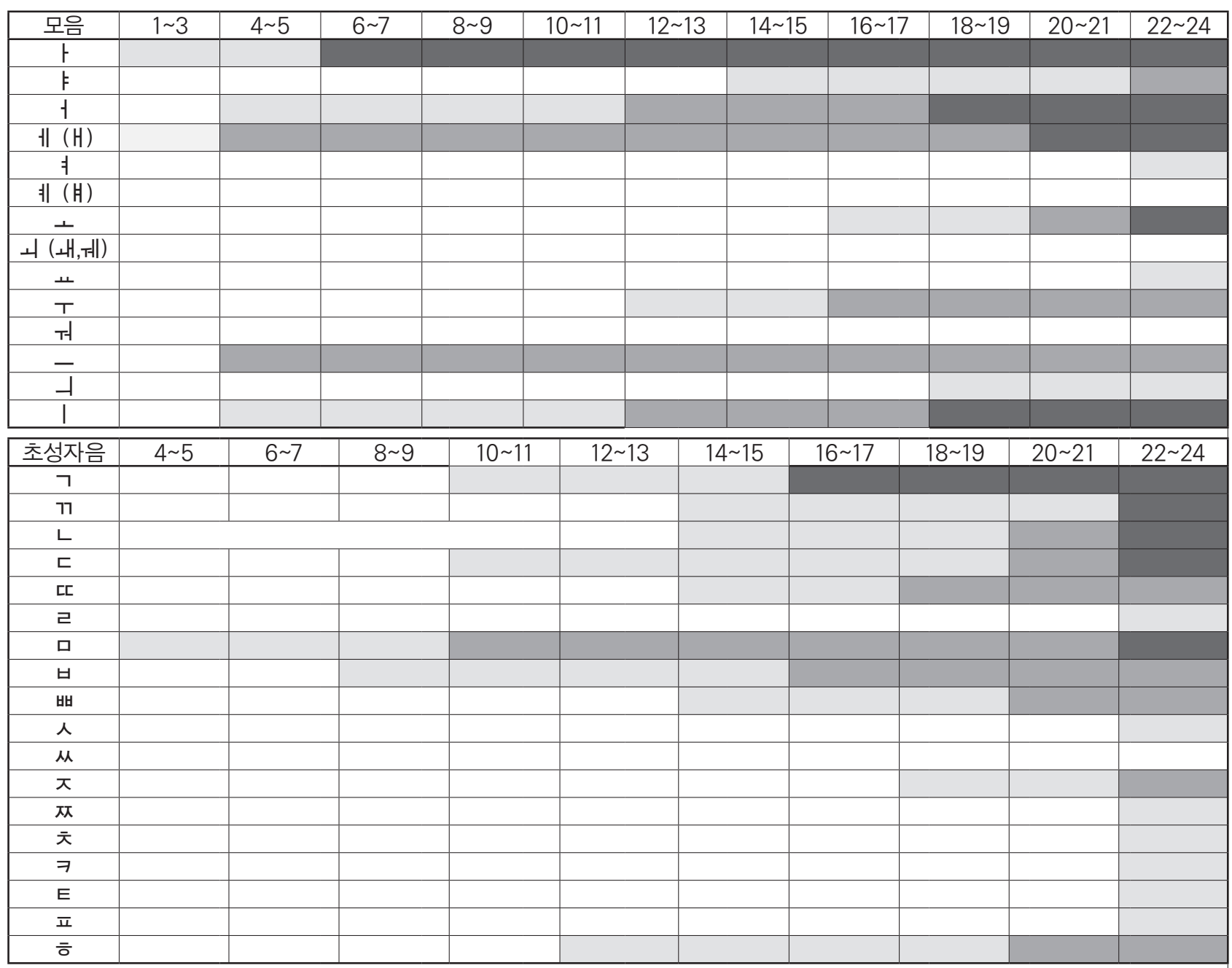

\begin{tabular}{|c|c|c|c|c|c|c|c|c|c|c|}
\hline 종성자음 & $4 \sim 5$ & $6 \sim 7$ & $8 \sim 9$ & $10 \sim 11$ & $12 \sim 13$ & $14 \sim 15$ & $16 \sim 17$ & $18 \sim 19$ & $20 \sim 21$ & $22 \sim 24$ \\
\hline 7 & & & & & & & & & & \\
\hline L & & & & & & & & & & \\
\hline ᄃ & & & & & & & & & & \\
\hline ᄅ & & & & & & & & & & \\
\hline 口 & & & & & & & & & & \\
\hline ㅂ & & & & & & & & & & \\
\hline 0 & & & & & & & & & & \\
\hline
\end{tabular}

